\title{
Hydrogen cyanamide breaks grapevine bud dormancy in the summer through transient activation of gene expression and accumulation of reactive oxygen and nitrogen species
}

\author{
Boonyawat Sudawan', Chih-Sheng Chang ${ }^{2}$, Hsiu-fung Chao ${ }^{3}$, Maurice S. B. Ku ${ }^{4,5^{*}}$ and Yung-fu Yen ${ }^{4^{*}}$ (D)
}

\begin{abstract}
Background: Hydrogen cyanamide $(\mathrm{HC})$ and pruning $(\mathrm{P})$ have frequently been used to break dormancy in grapevine floral buds. However, the exact underlying mechanism remains elusive. This study aimed to address the early mode of action of these treatments on accumulation of reactive oxygen species (ROS) and reactive nitrogen species (RNS) and expression of related genes in the dormancy breaking buds of grapevine in the summer.

Results: The budbreak rates induced by pruning (P), hydrogen cyanamide (HC), pruning plus hydrogen cyanamide (PHC) and water (control) after 8 days were 33, 53, 95, and $0 \%$, respectively. Clearly, HC was more effective in stimulating grapevine budbreak and P further enhanced its potency. In situ staining of longitudinal bud sections after $12 \mathrm{~h}$ of treatments detected high levels of ROS and nitric oxide (NO) accumulated in the buds treated with PHC, compared with $\mathrm{HC}$ or $\mathrm{P}$ alone. The amounts of ROS and $\mathrm{NO}$ accumulated were highly correlated with the rates of budbreak among these treatments, highlighting the importance of a rapid, transient accumulation of sublethal levels of ROS and RNS in dormancy breaking. Microarray analysis revealed specific alterations in gene expression in dormancy breaking buds induced by $\mathrm{P}, \mathrm{HC}$ and $\mathrm{PHC}$ after $24 \mathrm{~h}$ of treatment. Relative to control, $\mathrm{PHC}$ altered the expression of the largest number of genes, while $\mathrm{P}$ affected the expression of the least number of genes. PHC also exerted a greater intensity in transcriptional activation of these genes. Gene ontology $(\mathrm{GO})$ analysis suggests that alteration in expression of ROS related genes is the major factor responsible for budbreak. qRT-PCR analysis revealed the transient expression dynamics of 12 specific genes related to ROS generation and scavenge during the $48 \mathrm{~h}$ treatment with PHC.

Conclusion: Our results suggest that rapid accumulation of ROS and NO at early stage is important for dormancy release in grapevine in the summer, and the identification of the commonly expressed specific genes among the treatments allowed the construction of the signal transduction pathway related to ROS/RNS metabolism during dormancy release. The rapid accumulation of a sublethal level of ROS/RNS subsequently induces cell wall loosening and expansion for bud sprouting.
\end{abstract}

Keywords: Hydrogen cyanamide, ROS, Dormancy breaking buds, Grapevines, Gene ontology

\footnotetext{
* Correspondence: mku@mail.ncyu.edu.tw; yfyen@mail.ncyu.edu.tw

${ }^{4}$ Department of Bioagricultural Sciences, National Chiayi University, Chiayi

60004, Taiwan

Full list of author information is available at the end of the article
} 


\section{Background}

Grapevine is a perennial crop in temperate climates and perceives short day petoperiod and cool temperatures as signals to onset bud endodromancy to survive winter conditions; subsequently it requires exposure to adequate chilling temperatures for several weeks (or months) to end the dormancy [1-3]. Endodormancy is regulated by the physiological factors inside the affected buds [3, 4]. Abascisic acid (ABA) accumulates during the development of endodormancy in grapevine by suppression of bud meristem activity and its degradation is critical for dormancy release [5]. Furthermore, ethylene is suggested to participate in the degradation of ABA and budbreak by modulating the expression of ABA signaling regulators $[5,6]$. Grapevine grown in subtropical regions often exhibits non-uniform or delayed budbreak in early spring due to warm winter that provides inadequate chilling. This represents a major obstacle for the commercial production of table grapes. Hydrogen cyanamide $\left(\mathrm{H}_{2} \mathrm{CN}_{2}, \mathrm{HC}\right)$ has been found very effective for breaking the dormancy of floral buds in grapevine [7-9], kiwifruit [10] and apple $[11,12]$. In subtropical regions, $\mathrm{HC}$ treatment on intact dormant buds in spring is an important grapevine orchard management practice to induce uniform budbreak. In Taiwan, a subtropical region, this treatment is also a common practice in mid-summer for the second grapevine harvest in the winter, where paradormant buds on the pruned canes can be treated with $\mathrm{HC}$ to ensure effective budbreak. Paradormancy in the latent buds in the summer is regulated by plant growth regulators originating from other organs, such as auxin from the apical meristem, affecting apical dormancy $[3,4]$. Few studies have been focused on the mechanism of paradormancy and its release by HC. An understanding of the biochemical and molecular bases underlying the release of dormancy by $\mathrm{HC}$ is critical for commercial production of grapes in subtropical and tropical regions.

$\mathrm{HC}$ is commonly used as a nitrogen fertilizer with herbicidal and fungicidal effects. It is readily taken up by plant tissues and rapidly decomposed by cyanamide hydratase to urea, followed by urease to ammonium [13]. Rapid detoxification of the highly toxic ammonia is achieved by the GOGAT pathway to produce arginine, histadine and lysine. However, cyanamide is also a very reactive substance and belongs to the classic nitriles. Nitrile hydratases metabolize nitriles to the corresponding amides glutamine and asparagine. However, at high concentrations it is toxic to plants when the enzymatic breakdown of cyanamide exceeds the ammonia detoxification capacity. Cyanamide is well known for its effect to break dormant buds of fruit trees. The most dramatic physiological effect of cyanamide to plants is its strong inhibition of catalase, caused by the reaction of the nitrile group with the thiols and haematin of the enzyme, and the subsequent increase in $\mathrm{H}_{2} \mathrm{O}_{2}$ content [13]. After $\mathrm{HC}$ application, cyanide $(\mathrm{CN})$ is released and breaks dormant flower buds in Prunus species [14]. Cyanide is also a coproduct of cyanogenic glucoside hydrolysis $[6,15,16]$. Cyanide is toxic to plants by arresting aerobic respiration (e.g. cellular hypoxia) and energy production. Consequently, a shift to anaerobic respiration is induced.

Plants respond to $\mathrm{HC}$ or potassium cyanide $(\mathrm{KCN}$, respiration inhibitor) by eliciting the reactive oxygen species (ROS) such as $\mathrm{H}_{2} \mathrm{O}_{2}$, as shown in sunflower seeds $[15,17]$ and in grapevine buds $[15,18]$. Hypoxia $\left(8 \% \mathrm{O}_{2}\right)$, and two inhibitors of respiration (e.g. $\mathrm{KCN}$ and sodium nitroprusside) also triggers the production of $\mathrm{H}_{2} \mathrm{O}_{2}$ and ethylene, which in turn activates the antioxidant systems in grapevine buds through the mediation of the these signaling molecules [19]. Consistently, during germination the seeds develop an anaerobic condition after imbibition due to the rapid consumption of $\mathrm{O}_{2}$ and the barrier imposed by the seed coat for gas exchanges, and the depletion of $\mathrm{O}_{2}$ in seeds is accompanied by an increase in $\mathrm{H}_{2} \mathrm{O}_{2}$ and $\mathrm{NO}$ levels [20]. Taken together, these results suggest that hypoxia maybe the primary cause that induces budbreak and the increased levels of ROS and NO are the secondary products produced in response to hypoxia. A general model accounting for the major events occurring during artificially induced bud dormancy release has been proposed $[5,7,19,21]$. In this model, upon $\mathrm{HC}$ treatment a respiratory disturbance in mitochondria leads to a transient oxidative stress expressed as an increased level of ROS, decreased activity of TCA cycle and decreased production of ATP and increased production of ethylene. To cope with energy crisis, alternative respiratory pathway, glycolysis, pyruvate metabolism and anaerobic respiration or fermentation is induced. In parallel, various antioxidant systems are upregulated to cope with the transient oxidative burst. However, the underlying mechanism leading to growth resumption remains elusive.

ROS are known to play a key role in cell wall loosening in growing tissues [22, 23] and act as signalling molecules in signal transduction in cells, regulating plant growth and development in response to biotic and abiotic stimuli $[24,25]$. In plant cells, ROS production is regulated spatially and temporally from many sources and ROS reactivities take place in various cellular components, such as chloroplast, mitochondria, peroxisome, endoplasmic reticulum, apoplast, plasma membrane and cell wall $[24,26-28]$, with mitochondria as the major source of ROS production [29, 30]. Accumulation of endogenous ROS in plants can be triggered by many environmental stresses, such as water deficit and salinity [31] and chilling stress [32], especially under high light or in combination with other stresses. Generation of ROS can 
be catalysed by many enzymes, such as glucose oxidase, xanthine oxidase, peroxidases, oxalate oxidases, amine oxidase, lipoxygenases, quinine reductases and NADPH oxidases [24, 33].

Membrane-bound NADPH oxidases, known as respiratory burst oxidase homologues (RBOHs), serve as important molecular 'hubs' during ROS mediated signalling in plants [33]. NADPH oxidases control plant growth and development by making ROS that regulate plant cell expansion through the activation of $\mathrm{Ca}^{2+}$ [34], integrating calcium signalling and protein phosphorylation with increasing ROS production [25]. Also, the bioreactive lipoxygenase (LOX) metabolites stimulate the activity of NADPH oxidases and production of ROS [35]. The major bulk of lipoxygenases (LOXs) is localized in the cytoplasm and vacuole of the plant cell [36]. Expression of $L O X$ is regulated by different forms of stress, such as wounding, water deficiency [37, 38], or pathogen attack [39]. Thus, NADPH oxidases have a dedicated function of generating ROS and act as key signalling nodes integrating multiple signal transduction pathways in plants $[40,41]$.

ROS in the form of $\mathrm{H}_{2} \mathrm{O}_{2}$ is moderately reactive and relatively long-lived that can pass freely through membranes by diffusion and acts as a messenger in the stress signalling response $[42,43] . \mathrm{H}_{2} \mathrm{O}_{2}$ upregulates transcription factors (TFs) and TF-interacting proteins, affecting cell division, stem branching, flowering time and flower development [44]. The gaseous nitrogen reactive species (NRS) NO may serve as an enhancer in the ROS generation network $[45,46]$. As a key signalling molecule, NO functions in different intercellular processes, including the expression of defense-related genes against pathogens and apoptosis/program cell death (PCD), maturation and senescence, stomatal closure, dormancy release during seed germination, root development and induction of ethylene emission. Recent studies showed that NO can be produced in plants by enzymatic and non-enzymetic systems. The major NO-producing enzymes in plants are nitrate reductase in a NADH-dependent reaction and several arginine-dependent nitric oxide synthase-like (NOS) activities in different cellular compartments [20, 47]. Other potential enzymatic sources of NO include NO synthase, xanthine oxidoreductase, peroxidase, cytochrome P450, and some hemeproteins.

To control ROS levels under oxidative stress, organisms induce a variety of antioxidant enzymes and compounds to scavenge ROS and RNS in the cells. Within a cell, the superoxide dismutases (SODs) in various cellular organelles constitute the first line of defense against ROS [48]. Other defense enzymes, including catalase (CAT), ascorbate peroxidase (APX), guaiacol peroxidase (GPX), glutathione reductase (GR), monodehydroascorbate reductase (MDHAR), and dehydroascorbate reductase (DHAR), protect their cellular constituents by scavenging the harmful ROS and thus maintaining the normal cellular redox state [49]. The antioxidant compounds ascorbate and glutathione serve as cofactors in some of these scavenging reactions. Earlier studies showed that $\mathrm{HC}$ inhibits grapevine bud catalase gene expression during the first 4 days of treatment, but induces transcripts for the enzymes pyruvate decarboxylase $(P D C)$ and alcohol dehydrogenase $(A D H)$ [50]. In grapevine buds, $\mathrm{HC}$ also upregulates oxidative stress-related genes, such as thioredoxin $\mathrm{h}(\operatorname{Tr} x h)$, glutathione S-transferase (GST), ascorbate peroxidase $(A P X)$, glutathione reductase $(G R)$, and hypoxia related genes, such as sucrose synthase $(S u S y)$ [51, 52]. After exposure to $\mathrm{HC}$, peroxidase activity in a number of plants is increased. Peroxidases utilize different organic electron donors to reduce $\mathrm{H}_{2} \mathrm{O}_{2}$. Natural chilling also leads to similar induction of these genes during the last stage of the dormancy cycle of grape buds [53]. Class 1 nonsymbiotic hemoglobin is involved in scavenging of NO [20, 54-57]. Its expression is increased during hypoxic stress, application of respiratory chain inhibitors (e.g. cyanide) and high level of nitrate.

Accumulation of excessive ROS (e.g. $\mathrm{H}_{2} \mathrm{O}_{2}$ ) and RNS (e.g., NO) in turn induces the activation of alternative electron-transport pathway to prevent accumulation of excessive ROS, and the expression of alternative oxidase gene $(A O X 1 a)$ is also known to respond to various stresses in plants [58]. The expression of $A O X 1$ affects both ROS and RNS generation and accumulation through the respiratory chain in mitochondria [59-61]. Expression of $A O X$ is up-regulated in grapevine buds by $\mathrm{HC}$ treatment [7], but $\mathrm{HC}$ treatment increased $\mathrm{H}_{2} \mathrm{O}_{2}$ production in grapevine buds [18]. Clearly, a complicate regulatory network controlling ROS metabolism exists in plant cells. Moreover, as many genes exist in a gene family whether all members in the family are affected by the same stimuli is not known. Thus, how HC exactly affects the ROS regulatory network during grapevine dormancy release remains unclear.

To gain a better understanding of the underlying mechanism of the release of paradormancy in the summer grapevine buds by $\mathrm{P}$ and $\mathrm{HC}$, this study aimed to follow the changes of endogenous ROS and NO levels in the intact dormancy breaking buds by cytochemical staining and identify the candidate genes being significantly altered by microarray analysis. GO categories that are related to ROS-generating, ROS-scavenging, and NO detoxification were identified as key early factors in grapevine dormant bud break. The expression dynamics of these factors during the early stages of budbreak support the importance of a rapid accumulation of ROS and RNS with a concomitant activation of related genes for budbreak. 


\section{Results}

\section{Budbreak rate}

After 8 days, the budbreak rates of dormant grapevine buds treated with $\mathrm{P}$ (pruning), $\mathrm{HC}$ (1\% or $12.5 \mathrm{mM}$ hydrogen cyanamide), PHC ( $\mathrm{P}+\mathrm{HC})$ and water (as a control) were 33.3, 53.3, 95.3 and $0 \%$, respectively (Fig. 1a). Obviously, HC alone was more effective in promoting dormant budbreak than $\mathrm{P}$. The effect of $\mathrm{HC}$ on breaking dormant buds was further enhanced by $\mathrm{P}$. A combined $\mathrm{P}$ and $\mathrm{HC}(\mathrm{PHC})$ treatment gave rise to the highest dormant budbreak, showing a synergetic interaction between $\mathrm{P}$ and $\mathrm{HC}$. During the treatment with $\mathrm{PHC}$, the breaking buds enlarged and sprouted rapidly between 96 and $192 \mathrm{~h}$ (Fig. 1b). Anatomical examination before and after $\mathrm{PHC}$ treatment showed an active growth resumption of floral meristem starting at $12 \mathrm{~h}$ (Fig. $1 \mathrm{C}$-c). Four to five leaf primordia were visible at $12 \mathrm{~h}$ and the inflorescence meristem began to develop at $48 \mathrm{~h}$ (Fig. $1 \mathrm{C}$-e), and the inflorescence primodia became well developed with complete floral meristem at $96 \mathrm{~h}$ post treatment (Fig. 1C-f).

\section{In situ detection of $\mathrm{H}_{2} \mathrm{O}_{2}, \mathrm{O}_{2}^{--}$and $\mathrm{NO}$}

The accumulation of $\mathrm{H}_{2} \mathrm{O}_{2}$ in the grapevine buds during the treatments was first quantitatively determined by measuring the $\mathrm{Fe}-\mathrm{H}_{2} \mathrm{O}_{2}$ complex in the buds [62]. For all four treatments, $\mathrm{H}_{2} \mathrm{O}_{2}$ increased rapidly and almost linearly, reaching its maximum level after $12 \mathrm{~h}$ and decreased slightly thereafter (Fig. 2), and the averaged amounts on a fresh weight basis were 1.38, 12.24, 22.06, and $29.31 \mu \mathrm{g} / \mathrm{g}$ for the control, $\mathrm{P}, \mathrm{HC}$, and PHC treatments, respectively. The accumulation of $\mathrm{H}_{2} \mathrm{O}_{2}$, $\mathrm{O}_{2}^{*-}$ and NO was subsequently examined by staining in situ in the bud longitudinal sections after $12 \mathrm{~h}$ of treatment. A similar pattern of accumulation among these treatments for $\mathrm{H}_{2} \mathrm{O}_{2}, \mathrm{O}_{2}^{--}$and $\mathrm{NO}$ was also observed, with the highest levels detected in the PHC treated buds and the lowest levels in the control buds. When the sections
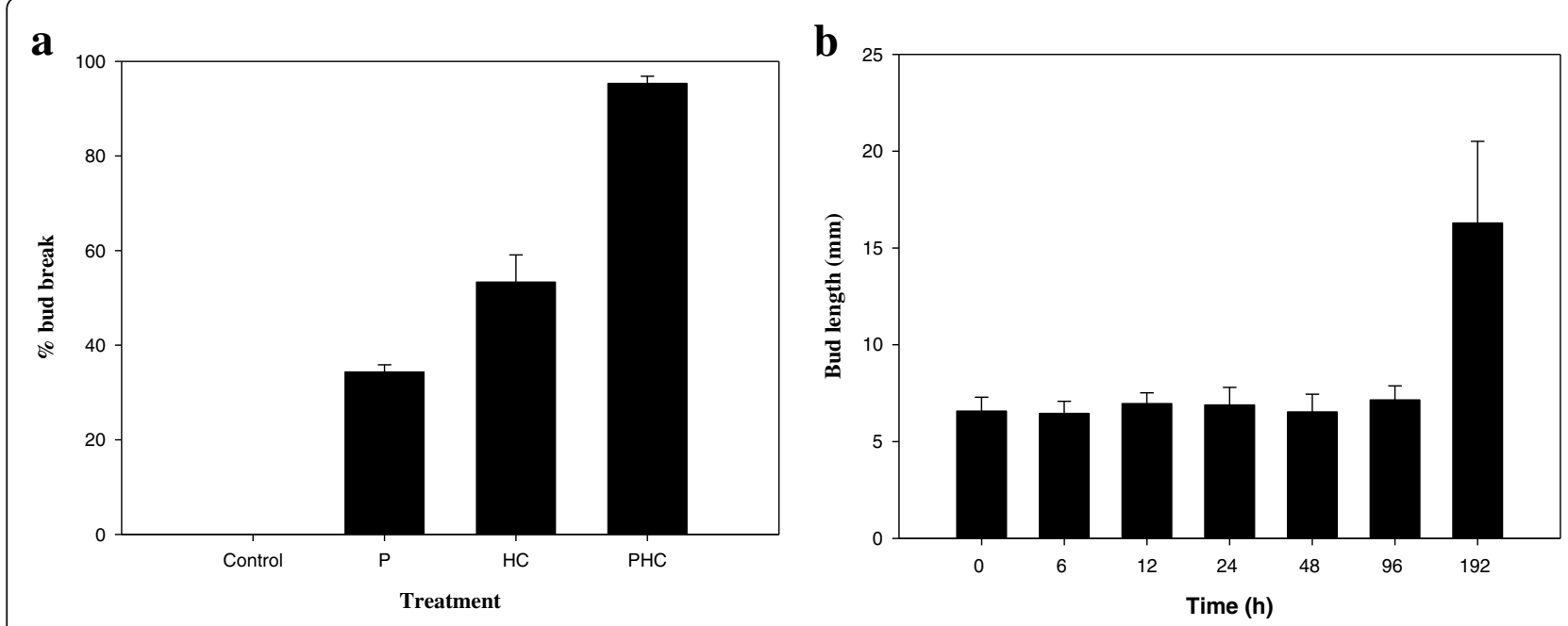

c

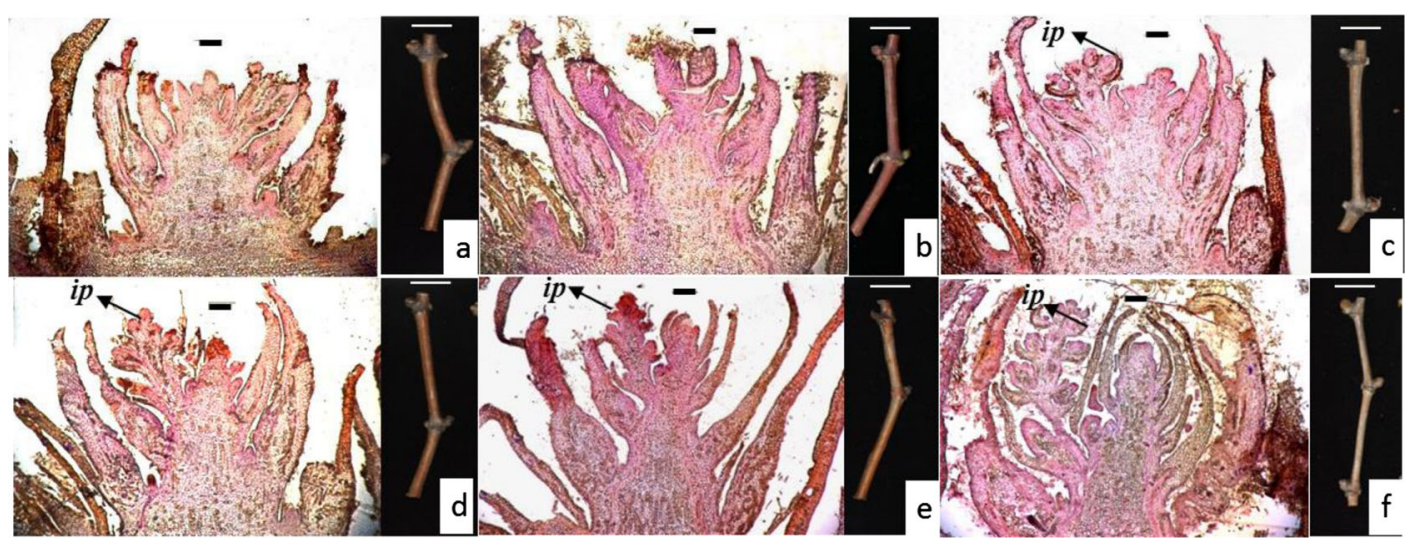

Fig. 1 Morphological and anatomical changes in grapevine buds during dormancy break. Percentages of budbreak after $192 \mathrm{~h}$ of treatment with P, HC, PHC, or water as a control ( $n=10$, bar: standard deviation) (A). Changes in bud length after PHC treatment at 0, 6, $12,24,48,96$ and 192 h ( $n=10$, bar: standard error) (B). Longitudinal sections of grapevine floral bud development during release of dormancy after PHC treatment: (a) 0 h, (b) 6 h, (c) 12 h, (d) 24 h, (e) 48 h and (f) 96 h. ip: inflorescence primordium (C). Bar: $200 \mu \mathrm{m}$ 


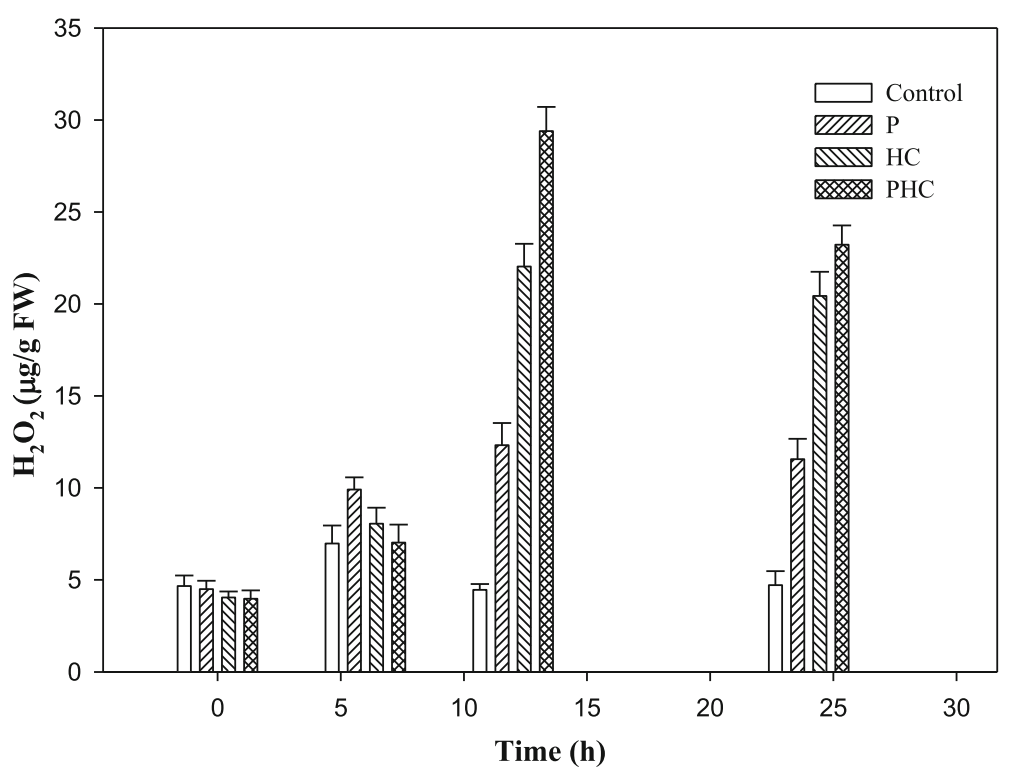

Fig. 2 Levels of $\mathrm{H}_{2} \mathrm{O}_{2}$ in the control, P, HC and PHC treated buds. Hydroperoxide was assayed by the ferric-xylenol orange (Fe-XO) complex [62]. After incubation in the dark for $30 \mathrm{~min}$, the absorbance was read at $560 \mathrm{~nm}$ with $100 \mu \mathrm{M}$ xylenol orange as blank

were incubated with specific scavengers of ROS or inhibitor of NO, no staining occurred, showing a low background as in the control sections. The results confirmed the specificity of the in situ staining of these reactive species. Thus, $\mathrm{H}_{2} \mathrm{O}_{2}, \mathrm{O}_{2}^{*-}$ and $\mathrm{NO}$ significantly accumulated in the sections of buds treated with $\mathrm{PHC}$, followed by $\mathrm{HC}$ and P (Fig. 3). The results suggest that intensive $\mathrm{H}_{2} \mathrm{O}_{2}, \mathrm{O}_{2}^{--}$ and $\mathrm{NO}$ production took place in the treated dormant buds at the early stage of budbreak. These levels are positively correlated with the percentages of budbreak (Fig. 1a).

\section{Microarray analysis of differentially expressed genes (DEGs) and clustering of expressed genes}

To gain insights into the early mode of molecular action during grapevine budbreak transcriptomic profiles in buds treated with $\mathrm{P}, \mathrm{HC}$ and $\mathrm{PHC}$ for $24 \mathrm{~h}$ were examined by microarray using Agilent $44 \mathrm{~K}$ Gene Expression Array with specific probes for grapevine genes. An earlier time course study showed that the numbers of up- and down-regulated genes in grapevine buds treated with $\mathrm{HC}$ reached the peak around $24 \mathrm{~h}$ post-treatment [7]. Clustering of the expressed genes into functional categories in the buds treated with $\mathrm{P}$, $\mathrm{HC}$, and PHC were based on GenSpring analysis, and the changes in transcript abundance were identified by M/A plot. A larger distribution of transcript abundance was found in the buds treated with $\mathrm{PHC}$, followed by $\mathrm{HC}$ and P (Additional file 1), consistent with its strong potency on dormancy release. However, it must be pointed out that transcriptional activation of some genes that occurred within $24 \mathrm{~h}$ of treatment may have not been identified.

\section{Identification of common differentially expressed genes (DEGs) among treatments}

Analysis by GenSpring indicated that a total of 965 , 1662 and 3783 genes showed significantly up-regulated expression and a total of 287, 1511 and 3261 genes showed significantly down-regulated expression by $\mathrm{P}$, $\mathrm{HC}$ and PHC treatments, respectively (Fig. 4a, b). Clearly, alteration in expression of many genes is involved in dormant budbreak in grapevine and many more genes were up-regulated than down-regulated by these treatments, similar to that reported in grape after treatment with $\mathrm{HC}$ [7]. 239 up-regulated and 106 downregulated genes were common for all three treatments, indicating similar molecular events occurred in these buds (Additional file 2). Among the commonly upregulated genes with a greater than a log2-fold change in expression are those coding for TF factors (e.g. 7 bHLHs, 2 WRKYs, EGL, ERF073, NAM-B1, OFP5 and HEC2) and functional genes coding for protein kinase, peroxidase, ion oxygenase, amine oxidase, PR proteins, dirigent proteins, expansin and extension (Table 1). The expression of some genes related to degradation of cyanamide (e.g. bifunctional nitrilase and nitrile hydratase), synthesis of pigments (e.g. stilbene, anthocyanidin) and metabolism of growth regulators (e.g. ethylene, salicylic acid, brassinosteroid, auxin and cytokinin) was also upregulated. In particular, the hypoxia related gene coding for sucrose synthase (SuSy) was significantly upregulated by all three treatments, especially by PHC. Among the commonly down-regulated genes are those coding for TFs (e.g. ERF016, ERF010-like, DET010-like, NAC18, NAC29, NAC100, FUS3, MYB24, A-7a-like, 


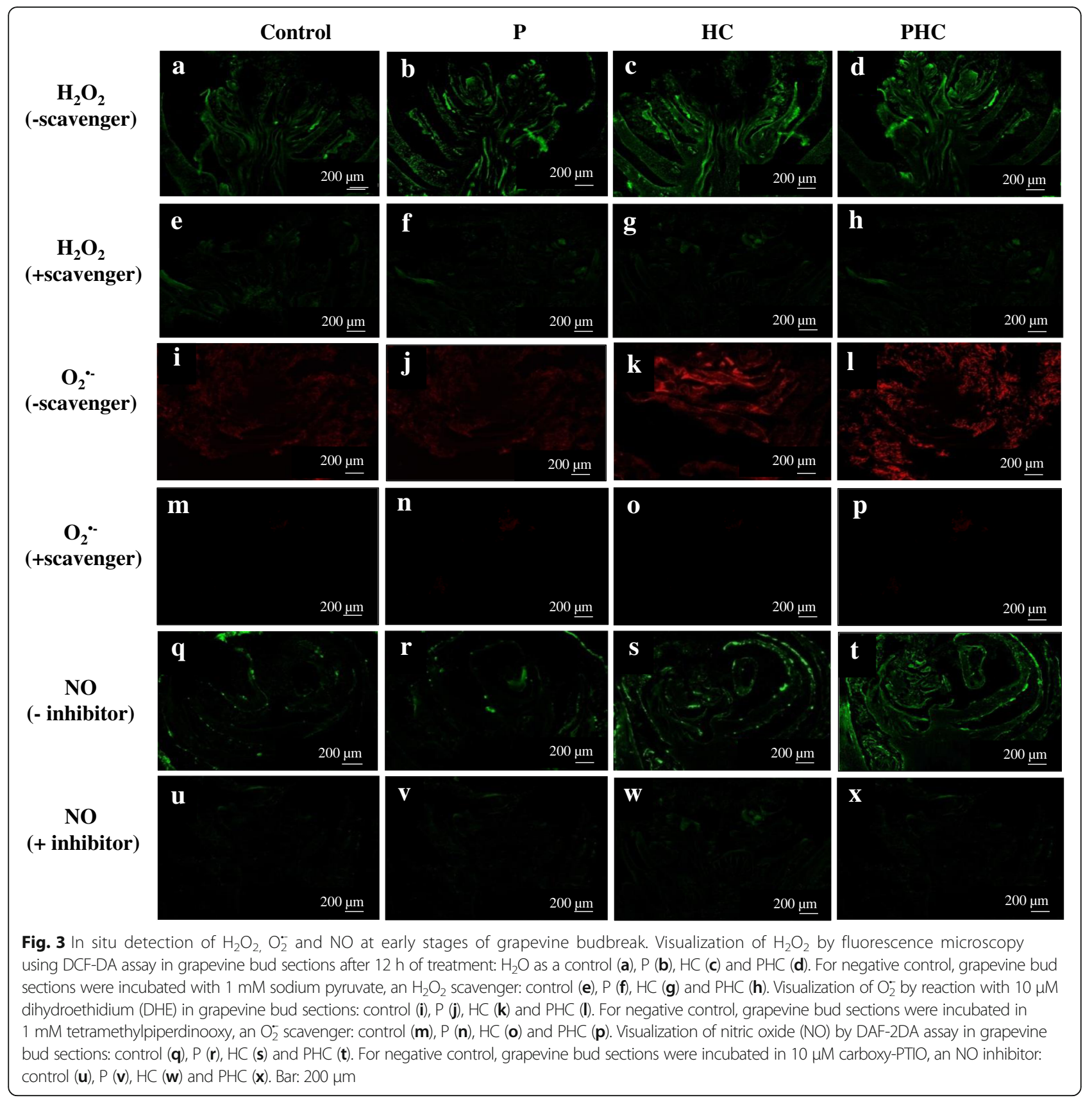

ABI5, GATA 24-like, ATHB-2, ATHB40) and functional genes coding for chloroplast chaperone danJ11, PR proteins, protein kinase, ubiquitin ligase, cytochrome P-450 and peroxidase 10 and 25 . These genes are generally related to stress responses in hormonal action, ROS metabolism, and transition to growth resumption process.

Classification of up- and down- regulated genes involved in ROS/NO metabolism

GO categories by ErmineJ analysis of ROS related genes that were up- or down-regulated in molecular function
$24 \mathrm{~h}$ post-treatment were listed in Table 2. Many ROSand NO-related genes showed significant alteration in expression. We identified clear overlaps of the molecular functions among the up- and down-regulated genes in response to $\mathrm{P}, \mathrm{HC}$ and $\mathrm{PHC}$ treatments. $\mathrm{GO}$ terms in which their gene expression levels altered significantly (by at least two fold) by the treatments were listed in Additional file 3. PHC induced more up- and downregulated genes than $\mathrm{HC}$ and $\mathrm{P}$ treatments. Also, there are genes commonly regulated by all three treatments. Among the ROS-generating genes, the two respiratory 


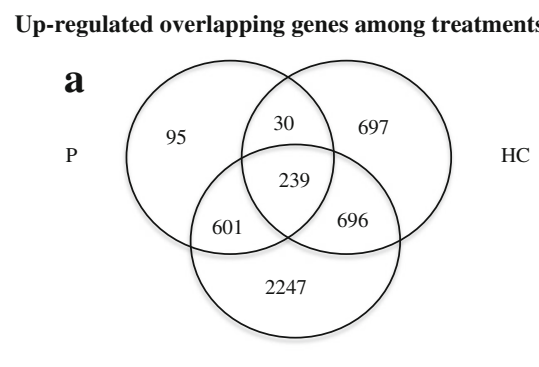

PHC

\section{Down-regulated overlapping genes among treatments}

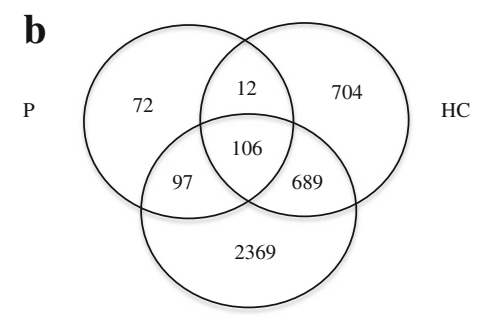

PHC

Fig. 4 Venn diagrams to show the overlap of significantly up- and down-regulated genes among different treatments. Comparison of significantly up- (a) and down-regulated genes (b) among P, HC and PHC treatments after $24 \mathrm{~h}$ of treatment. Microarray data analyses yielded 6410 significantly up- and 5059 significantly down-regulated genes by the 3 treatments with at least two fold changes $(p<0.05, n=3)$

Table 1 Functions of important transcription factors and proteins

\begin{tabular}{|c|c|}
\hline TFs or proteins & Function \\
\hline \multicolumn{2}{|l|}{ Up-regulated } \\
\hline 1. bHLH & bHLHs have a range of different roles in plant cell and tissue development as well as plant metabolism. \\
\hline 2. WRKY & $\begin{array}{l}\text { Regulators involved in various develop006Dental and physiological process, especially in coping with } \\
\text { diverse biotic (e.g. wounding, salicylic acid, cold, and salinity) and abiotic (e.g. methyl jasmonate (MeJA) stresses. }\end{array}$ \\
\hline 3. ERF & $\begin{array}{l}\text { Plays a crucial role in plant growth and development and in response to biotic and abiotic stress conditions in plant. } \\
\text { It's also involved in fruit ripening and stress processes. }\end{array}$ \\
\hline 4. NAM-B1 & $\begin{array}{l}\text { Acts in tissue specific manner to regulate monocarpic senescence and grain filling, and it's related to carbohydrate } \\
\text { metabolism in stems and the grain, and associated with the grain protein content in Fennoscandian wheat. }\end{array}$ \\
\hline 5. Protein kinase & Protein kinases are universal signal transduction modules in eukaryotes, including yeasts, animals and plants. \\
\hline 6. Peroxidase & $\begin{array}{l}\text { Peroxidases as key players during the whole life cycle of a plant, and particularly in cell wall modifications, and in } \\
\text { roles that can be antagonistic depending on the developmental stage. }\end{array}$ \\
\hline 7. Amine oxidase & $\begin{array}{l}\text { Cell wall maturation and lignification during development as well as with wound-healing and cell wall } \\
\text { reinforcement during pathogen invasion. }\end{array}$ \\
\hline 8. NADPH oxidase & A plasma membrane NADPH oxidase produces ROS in planta or in elicited cells during incompatible interaction \\
\hline 9. PR proteins & $\begin{array}{l}\text { The class } 1 \text { pathogenesis-related (PR) proteins are thought to be involved in plant defense responses against } \\
\text { infection by pathogens, such as fungi or viruses. }\end{array}$ \\
\hline 10. Expansin & Expansins are involved in enhancing growth by mediating cell wall loosening. \\
\hline 11. Extensin & $\begin{array}{l}\text { Extensins are involved in defense and in the control of extension growth by differential expressing under stress } \\
\text { and non-stress conditions. Extensin genes are developmentally regulated and induced by wounding, } \\
\text { methyl jasmonate, abscisic and salicylic acid. }\end{array}$ \\
\hline
\end{tabular}

Down-regulated

1. NAC

NAC has a variety of important functions in plant development, and also in abiotic stress responses.

2. FUS3

A positive regulator of seed responses to ABA and mediates osmotic stress responses during seed development.

3. MYB Regulation of anthocyan
-3-O-glucosyltransferase).

4. $\mathrm{ABI}$

Insensitive to $A B A$ in seed germination, with an earlier flowering phenotype.

5. GATA-like GATA DNA motifs have been implicated in light-dependent and nitrate-dependent control of transcription. the activity of procambial and cambial cells to differentiate, ATHB2 and ATHB4 genes are strongly induced by far-red-rich light.

7. Chaperone dna」 Regulation of the heat shock response by serving as an important pathway for the folding of newly synthesized polypeptides.

8. Ubiquitin ligase Ubiquitin ligase is an important part of cellular regulation in Arabidopsis, suggesting a major role for protein degradation in control of plant life. 
Table 2 Number of genes that were expressed in each treatment, as identified by GO categories

\begin{tabular}{|c|c|c|c|c|c|}
\hline \multirow[t]{2}{*}{ ROS-/NO-related genes } & \multirow[t]{2}{*}{ GO category } & \multirow[t]{2}{*}{ Gene family } & \multicolumn{3}{|c|}{ No. of gene up/down regulated } \\
\hline & & & $\bar{P}$ & $\mathrm{HC}$ & $\mathrm{PHC}$ \\
\hline \multicolumn{6}{|l|}{ ROS-related genes } \\
\hline \multirow[t]{2}{*}{ ROS-generating genes } & $\begin{array}{l}\text { GO:0043167 } \\
\text { ion binding }\end{array}$ & Respiratory burst oxidase homolog protein ( $\mathrm{VVRBOH})$ & $0 / 0$ & $0 / 1$ & $0 / 2$ \\
\hline & $\begin{array}{l}\text { GO:0004601 } \\
\text { peroxidase activity }\end{array}$ & Peroxidase (VvPOD) & $10 / 1$ & $10 / 14$ & $15 / 10$ \\
\hline \multirow[t]{6}{*}{ ROS-scavenging genes } & \multirow{6}{*}{$\begin{array}{l}\text { GO:0016209 } \\
\text { antioxidant activity }\end{array}$} & Alpha-dioxygenase 1 (VvDOX1) & $1 / 0$ & $1 / 0$ & $0 / 0$ \\
\hline & & Glutathione peroxidase (VvGPX) & $0 / 0$ & $0 / 1$ & $1 / 1$ \\
\hline & & Catalase isozyme 1-like (VvCAT) & $0 / 0$ & $0 / 2$ & $0 / 2$ \\
\hline & & Cytosolic ascorbate peroxidase (VVAPX) & $0 / 0$ & $0 / 1$ & $0 / 2$ \\
\hline & & Superoxide dismutase [Fe], chloroplastic (VvFSD) & $0 / 0$ & $0 / 0$ & $1 / 1$ \\
\hline & & Alternative oxidase 2, mitochondrial (VvAOX2) & $0 / 0$ & $1 / 0$ & $1 / 0$ \\
\hline \multirow[t]{3}{*}{ ROS-specific transcription factors } & \multirow{3}{*}{$\begin{array}{l}\text { GO:00037000 } \\
\text { transcription factor }\end{array}$} & Heat Stress transcription factor (VVHSF) & $0 / 1$ & $2 / 2$ & $3 / 6$ \\
\hline & & Ethylene response element binding factor (VvERF) & $4 / 3$ & $8 / 6$ & $8 / 9$ \\
\hline & & WRKY transcription factor (VvWRKY) & $1 / 0$ & $9 / 4$ & $7 / 7$ \\
\hline \multicolumn{6}{|l|}{ NO-related gene } \\
\hline NO-scavenging & $\begin{array}{l}\text { GO:0005488 } \\
\text { Binding }\end{array}$ & Hemoglobin-2 (VvHB2) & $0 / 0$ & $1 / 0$ & $1 / 0$ \\
\hline
\end{tabular}

These were significantly up/down regulated genes related to ROS/NO metabolism in grapevine buds treated with P, HC and PHC following the GO categories by ErmineJ analysis

burst oxidase homolog genes related to GO:0043167 (ion binding), $V v R B O H E$ and $V v R B O H A$, were downregulated by $\mathrm{PHC}$, while only $V v R B O H A$ was downregulated by HC. However, VvRBOHE was upregulated by $\mathrm{P}$ and $\mathrm{HC}$.

The ROS-scavenging peroxidases related to GO:0004601 exist in a big gene family, and many of $V v P O D$ genes were up-/down-regulated, especially by HC and PHC (10/14, and 15/10). Obviously, most of the POD genes were upregulated and they are assumed to play a key role in the reduction of $\mathrm{H}_{2} \mathrm{O}_{2}$ in grapevine buds treated with $\mathrm{HC}$ [13]. For other ROS-scavenging genes in GO:0016209 (antioxidant activity), the expressions of five gene families have been upor down-regulated by the three treatments. For example, one alpha-dioxygenase gene $(V v D O X 1)$ was up-regulated by $\mathrm{P}$ and $\mathrm{HC}$, but not by PHC. Gene coding for glutathione peroxidase ( $V v G P X 2)$ was up-regulated by $\mathrm{PHC}$ whereas another $(V v G P X 8)$ gene was down-regulated by $\mathrm{HC}$ and PHC. After 24 h of treatment, two catalase isozyme 1-like genes $(V v C A T)$ were down-regulated by both $\mathrm{HC}$ and PHC. In addition, $V v A P X$ coding for cytosolic ascorbate peroxidase was down-regulated by both $\mathrm{HC}$ and $\mathrm{PHC}$, and $V v F S D$ coding for chloroplastic superoxide dismutase (SOD) [Fe] was down-regulated by $\mathrm{PHC}$ whereas $V v F S D 3$ was up-regulated by PHC. The expression of $V v A O X$ that codes for alternative oxidase in mitochondria was upregulated by both $\mathrm{HC}$ and $\mathrm{PHC}$. For $\mathrm{NO}$ related genes, the expression of hemoglobin-2 gene (VvHB2) in binding (GO:0005488) was significantly up-regulated by both $\mathrm{HC}$ and PHC. The expression of the genes in the three ROS related transcription factor gene families (GO:0003700), namely heat stress transcription factor $(V v H S F)$, ethylene response element binding factor (VvERF) and WRKY transcription factor $(V v W R K Y)$, was also differentially altered. The numbers of $V v H S F$ genes up-/down-regulated by $\mathrm{P}, \mathrm{HC}$, and $\mathrm{PHC}$ were $0 / 1,2 / 2$, and $3 / 6$, respectively, while the numbers of $V v E R F$ genes up-/down-regulated expressed by these treatments were $4 / 3,8 / 6$, and $8 / 9$, respectively. Many of the VvWRKY genes were also up- $/$ down-regulated, especially by $\mathrm{HC}$ and $\mathrm{PHC}(9 / 4$ and $7 / 7)$, compared to $\mathrm{P}(1 / 0)$. These results indicate that more genes are altered in their expression at a higher intensity by PHC and the expressions of different genes in the same GO category are differentially regulated by these treatments.

\section{Expression dynamics of ROS/NO-related genes during PHC treatment}

Quantitative RT-PCR (qRT-PCR) was used to confirm the alteration in expression of 12 selected DEGs identified by cDNA microarray and profile the expression dynamics of these genes during the $48 \mathrm{~h}$ of PHC treatment using eIF4A as a reference gene as its expression did not change substantially [1]. The DEGs included 2 genes coding for ROSgenerating ( $V v R B O H E, V v R B O H A), 9$ genes coding for ROS-scavenging ( $V v P O D 72$, and $V v P O D 12, V v D O X 1$, $V v G P X 2, V v A P X 3, V v F S D 3, V v F S D, V v A O X 2, V v C A T 1)$ and one gene coding for NO-scavenging ( $V v H B 2)$ (Table 3). The expression profiles of these 12 genes during 
Table 3 List of genes that were used to profile their expression dynamics by qRT-PCR

\begin{tabular}{|c|c|c|c|c|}
\hline \multirow[t]{2}{*}{ Gene Locus ID } & \multirow[t]{2}{*}{ Gene description } & \multicolumn{3}{|c|}{ Normalized Fold $\left(\log _{2}\right)$} \\
\hline & & $\mathrm{P}$ & $\mathrm{HC}$ & PHC \\
\hline GSVIVT00016386001 & Vitis vinifera respiratory burst oxidase homolog protein E (VvRBOHE) & $0.30 \pm 0.21$ & $1.11 \pm 0.18$ & $-1.22 \pm 0.06$ \\
\hline GSVIVT00002525001 & Vitis vinifera respiratory burst oxidase homolog protein $A(V v R B O H A)$ & $-0.64 \pm 0.06$ & $-1.53 \pm 0.29$ & $-1.96 \pm 0.16$ \\
\hline GSVIVT00031598001 & Vitis vinifera peroxidase 72 (VvPOD72) & $1.59 \pm 0.77$ & $2.09 \pm 1.18$ & $4.19 \pm 0.18$ \\
\hline GSVIVT00031723001 & Vitis vinifera peroxidase 12 (VvPOD12) & $-0.79 \pm 0.05$ & $-0.74 \pm 0.25$ & $-1.71 \pm 0.13$ \\
\hline GSVIVT00020782001 & Vitis vinifera alpha-dioxygenase 1 (VvDOX1) & $1.83 \pm 1.16$ & $2.82 \pm 0.55$ & $0.13 \pm 0.25$ \\
\hline GSVIVT00001920001 & Vitis vinifera glutathione peroxidase 2 (VvGPX2) & $0.34 \pm 0.39$ & $0.28 \pm 0.45$ & $1.10 \pm 0.54$ \\
\hline GSVIVT00004080001 & Vitis vinifera catalase isozyme 1-like (VvCAT1) & $-0.35 \pm 0.17$ & $-1.52 \pm 0.02$ & $-1.57 \pm 0.15$ \\
\hline GSVIVT00036747001 & Vitis vinifera cytosolic ascorbate peroxidase (VvAPX3) & $-0.47 \pm 0.24$ & $-1.05 \pm 0.09$ & $-1.75 \pm 0.04$ \\
\hline GSVIVT00007083001 & Vitis vinifera superoxide dismutase [Fe] 3, chloroplastic (VvFSD3) & $0.40 \pm 0.17$ & $0.17 \pm 0.10$ & $1.82 \pm 0.11$ \\
\hline GSVIVTO0014163001 & Vitis vinifera superoxide dismutase [Fe], chloroplastic (VvFSD) & $0.50 \pm 0.13$ & $0.33 \pm 0.22$ & $-1.60 \pm 0.17$ \\
\hline GSVIVT00003173001 & Vitis vinifera alternative oxidase 2, mitochondrial (VvAOX2) & $0.44 \pm 0.16$ & $2.43 \pm 0.37$ & $1.07 \pm 0.18$ \\
\hline GSVIVT00036443001 & Vitis vinifera hemoglobin-2 (VvHB2) & $-0.52 \pm 0.43$ & $4.41 \pm 0.34$ & $3.08 \pm 0.43$ \\
\hline
\end{tabular}

These include twelve differentially expressed genes related to ROS/NO metabolism in grapevine buds treated with $\mathrm{P}, \mathrm{HC}$ or $\mathrm{PHC}$ for $24 \mathrm{~h}$, as revealed by microarray analysis

the $48 \mathrm{~h}$ treatment showed different tempos, with most of their expression peaked at 6 or $12 \mathrm{~h}$, indicating a transient nature. A similar trend in gene expression was also reported in detached grapevine canes treated with $\mathrm{HC}$ or heat shock (HS) [7]. Two of the ROS-generating respiratory burst oxidase homologue genes, $V v R B O H E$ and $V v R B O H A$, and the scavenging peroxidase gene $V v P O D 12$ were down-regulated by more than two folds throughout the first $48 \mathrm{~h}$ of treatment. In significant contrast, the expression of the peroxidase gene $V v P O D 72$ started to increase after $6 \mathrm{~h}$ of treatment and reached its maximum expression at $12 \mathrm{~h}$ (14.8 fold), but dropped off to normal levels thereafter, consistent with the results obtained by microarray (Table 3). Thus, $V v P O D 72$ and several other members of the peroxidase family (Table 2) played an important role in early ROS metabolism by scavenging $\mathrm{H}_{2} \mathrm{O}_{2}$ upon PHC treatment, which synchronized with the new meristem growth (Fig. 5a).

For other ROS-scavenging genes, the alpha-dioxygenase $V v D O X 1$ showed a rapid increase (24.6 fold) in transcript as early as $6 \mathrm{~h}$ post treatment and declined gradually throughout the treatment. A small increase (4.8 fold) in the glutathione peroxidase $V v G P X 2$ transcript was detected as early as $6 \mathrm{~h}$, but its expression accelerated rapidly thereafter and reached its maximum expression $(113.2$ fold) at $12 \mathrm{~h}$, but dropped off to 31.6 and 13.4 fold at 24
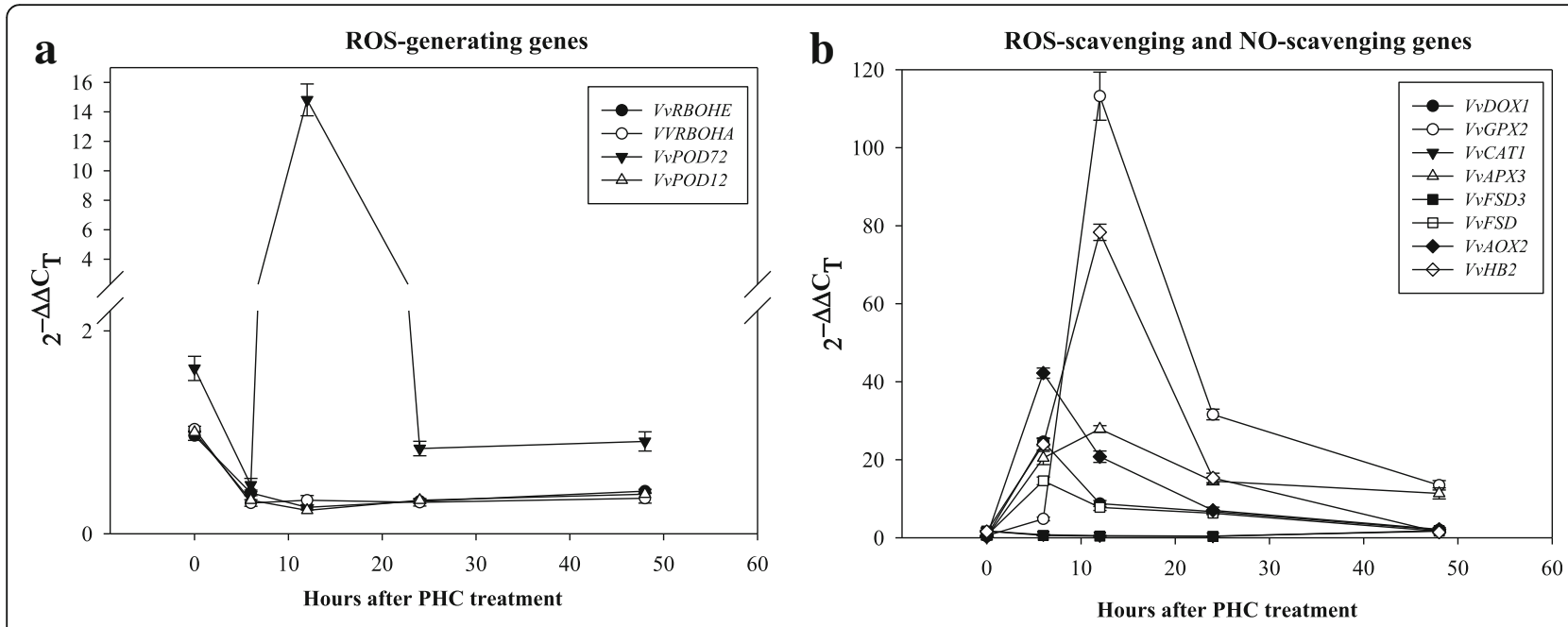

Fig. 5 Changes in transcript abundance of 12 up- and down-regulated ROS/NO-related genes during $48 \mathrm{~h}$ treatment with PHC, as analyzed by qRT-PCR. These include 4 ROS-generating genes (VVRBOHE, VVRBOHA, VVPOD72, VVPOD12) (a), and 7 ROS-scavenging genes (VVDOX1, VVGPX2, VVCAT1, VVAPX3, VVFSD3, VVFSD, VVAOX2) and one NO-scavenging gene (VVHB2) (b). The selection of these genes was based on their relative expression levels obtained by the microarray analysis (Table 3) 
and $48 \mathrm{~h}$, respectively. For the ascorbate peroxidase gene $V v A P X 3$, a rapid increase of transcript (20.4 fold) was detected as early as $6 \mathrm{~h}$ and reached its maximum expression (27.8 fold) at $12 \mathrm{~h}$ and slowly declined to 14.5 and 11.4 fold at 24 and $48 \mathrm{~h}$, respectively. Interestingly, VvFSD3 and $V v F S D$, both coding for chloroplastic superoxide dismutases (SODs), showed different expression patterns: $V v F S D 3$ expression decreased progressively from 0.6 fold at $6 \mathrm{~h}$ to 0.4 fold at $24 \mathrm{~h}$ after treatment but increased to 1.8 folds after $48 \mathrm{~h}$ of treatment, whereas the expression of $V v F S D$ showed a rapid increase as early as $6 \mathrm{~h}$ (14.6 fold) but declined gradually to a normal level at $48 \mathrm{~h}$. The mitochondrial alternative oxidase $V v A O X 2$ also showed a rapid increase in expression ( 42.2 fold) as early as $6 \mathrm{~h}$ but declined gradually to a normal level at $48 \mathrm{~h}$. It is also noticeable that the expression of the peroxisomal catalase isozyme-like $V \nu C A T 1$ was first down-regulated, decreasing progressively from 0.7 fold at $6 \mathrm{~h}$ to 0.5 fold at $24 \mathrm{~h}$, but increased to 1.8 fold after $48 \mathrm{~h}$ of treatment. The initial downregulation of catalase expression may have contributed to the rapid accumulation of $\mathrm{H}_{2} \mathrm{O}_{2}$ [13], but its subsequent rise in expression may have prevented the buildup of a lethal level of $\mathrm{H}_{2} \mathrm{O}_{2}$. A rapid increase in the hemoglobin-2 (VvHB2) transcript was detected at $6 \mathrm{~h}$ (23.9 fold) and it reached its maximum expression (78.3 fold) at $12 \mathrm{~h}$, but its transcript level dropped off from 15.33 at $24 \mathrm{~h}$ to 1.39 fold at $48 \mathrm{~h}$, similar to that reported in an earlier study [7]. This result suggests that the intensive expression of hemoglobin 2 is triggered by the treatment at very early stage of the treatment and may be important in scavenging NO. Taken together, these results suggest that the two NADPH oxidases, VvRBOHE and VvRBOHA, may not be a key player in ROS generation, while VvPOD72, VvDOX1, VvGPX2, VvAPX3 and VvHB2 are important for ROS and NO scavenging, respectively (Fig. 5b). Overall, these results are in agreement with those obtained by microarray analysis after $24 \mathrm{~h}$ of treatment with HC (Table 2, Additional file 3).

\section{Discussion}

$\mathrm{HC}$ has been frequently used to break endodormancy of floral buds in grape and several studies have been conducted to address its physiological and molecular basis $[4,8,9,13,63]$. However, study on its application to release paradormancy of grape floral buds in the summer has received very little attention. This study aimed to address the early mode of action of PHC, a combination of pruning and $\mathrm{HC}$, with intact grape canes on its effective alleviation of bud dormancy in hot summer that results in uniform budbreak and floral development without chilling requirement. PHC induced budbreak much more rapidly and efficiently than $\mathrm{P}$ or $\mathrm{HC}$ alone, indicating a synergetic interaction between $\mathrm{P}$ and $\mathrm{HC}$ treatments (Fig. 1a). Compared to the long period of time required for budbreak by chilling [64], the rapid induction of budbreak by PHC observed in this study may in part be due to the nature of dormancy and the warm temperatures in the summer which accelerate metabolism and growth. Large amounts of $\mathrm{H}_{2} \mathrm{O}_{2}, \mathrm{O}_{2}^{*-}$ and $\mathrm{NO}$ accumulated rapidly in the buds upon the treatments, especially by $\mathrm{PHC}$ (Fig. 3); and the amount of $\mathrm{H}_{2} \mathrm{O}_{2}$ in the buds increased almost linearly in the buds, reaching its maximum level within $12 \mathrm{~h}$ (Fig. 2). Moreover, the ROS levels accumulated are closely correlated with the percentage of budbreak among these treatments, and this strong, transient oxidative burst coincides with growth resumption in the buds (Fig. 1). Similarly, previous studies also showed that grape buds respond to $\mathrm{HC}$ and $\mathrm{KC}$ by eliciting ROS, such as $\mathrm{H}_{2} \mathrm{O}_{2}[18,19,65]$. Thus, a combination of $\mathrm{P}$ and $\mathrm{HC}$ is most effective in eliciting rapid accumulation of ROS and release of the paradormant buds in summer grapevine.

To provide insights into the molecular basis of $\mathrm{HC}$ effect on breaking dormant buds in grapevine, we conducted transcriptomic analysis during budbreak. Our transcriptomic profile provided a clear link between gene expression and ROS accumulation during the early stage of budbreak. Upon PHC treatment expression of a number of specific genes was altered rapidly to accommodate the metabolic activities required for budbreak and growth resumption. As expected, the numbers of significantly up-/down-regulated genes were highest in PHC treated buds, compared to $\mathrm{HC}$ and $\mathrm{P}$ treated buds (Fig. 4a, b). Moreover, PHC exerted a higher intensity of regulation, relative to other treatments. Although $\mathrm{P}, \mathrm{HC}$ and $\mathrm{PHC}$ induced dormant budbreak at varying degrees, many transcription factor (TF) and functional genes were commonly induced or suppressed by these treatments (Table 1). These genes/proteins must play important roles in budbreak response. Many of the upregulated TFs, such as WRKYs [66] and ERF (ethylene response factor) [67], are known to be involved in biotic and abiotic stress responses, whereas some other TFs, such as bHLH and NAM-B1, are related to cell and tissue development. For example, bHLHs exhibit a range of different roles in plant cell and tissue development [68], and NAM-B1 acts in a tissue specific manner to regulate monocarpic senescence and grain filling $[69,70]$. Consistently, ethylene biosynthesis is reported to increase in grape buds in response to $\mathrm{HC}$ and HS treatments and plays a key role in dormancy release by activating ERFs [7], and the high levels of ethylene accumulated in the submerged tissues promote shoot elongation [71] and parenchyma formation [72].

Many of the upregulated functional genes, such as protein kinase, peroxidase, amine oxidase, PR proteins, expansin and extension, are related to plant defense responses and cellular growth. For example, protein kinases are universal signal transduction modules in eukaryotes [73]. 
Amine oxidase that catalyzes the oxidative de-amination of polyamines and production of $\mathrm{H}_{2} \mathrm{O}_{2}$ has been correlated with cell wall maturation and lignification during development as well as wound-healing and cell wall reinforcement during pathogen invasion [26]. Peroxidases that catalyze the reduction of $\mathrm{H}_{2} \mathrm{O}_{2}$ are known to be involved in cell wall loosening [74]. Thus, these two enzymes may be the key players of ROS metabolism in the cell wall during dormant budbreak in grapevine, as exerted by PHC. PR proteins are thought to be involved in plant defense responses [75] and response to infection by pathogens [76]. In addition, expansin is related to cell wall loosening [77], while extensins expressed under stress and non-stress conditions (e.g. wounding, methyl jasmonate, abscisic acid and salicylic acid) $[78,79]$ are related to defense and control of extension growth [80]. Thus, these commonly induced TF and functional genes in stress response, oxidative burst, hormonal regulation, and reprogramming of cellular developmental and physiological processes must play important roles in the ROS regulatory network leading to dormancy breaking and bud sprouting in grapevine. Earlier microarray analyses with detached grapevine canes also suggest that $\mathrm{HC}$ and $\mathrm{HS}$ break the dormant buds through the link between sublethal stress, mitochondrial activity, temporary hypoxic conditions, ethylene metabolism, ROS scavenging activity and cell enlargement during bud dormancy release $[7,52]$.

Among the down-regulated TFs, NAC is known to be involved in biotic and abiotic stress response, FUS3 controls multiple elementary processes during seed development [81], $\mathrm{ABI} 5$ is related to insensitivity to $\mathrm{ABA}$ in seed germination and during embryogenesis [82], and ATHB regulates root hair development and promotes procambial and cambial vascular cell differentiation [83, 84]. In addition, MYB regulates proanthocyanidian biosynthesis in grapes [85], and GATA-like has been implicated in light-dependent and nitrate-dependent control of transcription [86]. Among the down-regulated functional genes, chaperone dnaJ regulates heat shock response [87] for proper folding of newly synthesized polypeptides [88] and ubiquitin ligases is an important part of cellular regulation in Arabidopsis [89]. Most of these responses may reflect temporary impairment of normal metabolic activities under the oxidative stress conditions.

\section{Expression dynamics of ROS metabolism related genes}

PHC triggered a rapid generation and accumulation of ROS and NO peaked at 12 h (Figs. $1 \mathrm{~b}, 2$ and 3), with a concomitant transcriptional activation of related genes peaked at $6-12 \mathrm{~h}$ post-treatment (Figs. 4 and 5). ROS levels are controlled by a network of generating and scavenging enzyme systems. For ROS generation, PHC highly induced $P O D 72$, but suppressed $R B O H E, R B O H A$ and $P O D 12$ at the early stages of treatment. Besides amine oxidase (Table 1), these results emphasize the importance of $P O D 72$ and other peroxidase members in ROS generation in cell wall during paradormant bud break in the summer grapevine. Consistently, previous results also suggest that peroxidase activity is increased largely in grapevine buds upon fulfilment of chilling requirement [64] and it may play an important role in consumption or release of ROS and in cell wall modification [74]. In response to oxidative burst genes coding for the various antioxidant systems, e.g. GPX2, CAT1, $A P X 3, A O X 2, D O X 1$ and $H B 2$, were also rapidly turned on in the dormancy breaking buds to scavenge ROS and NO. As reported earlier, after $12-24$ h of HC treatment, GR, GST and APX genes are upregulated in grapevine buds [7]. GPX and APX catalyze the reduction of hydrogen peroxide to water by using glutathione and ascorbate, respectively, as a specific electron donor [90]. In addition, glutathione is a strong detoxifying agent and has been shown to bind $\mathrm{HC}$ directly on its free thiol groups [91].

In Arabidopsis, $\alpha$-DOX fatty acid dioxygenase protects oxidative stress and cell death [92]. AOX1 is known to be induced by $\mathrm{H}_{2} \mathrm{O}_{2}$ and $\mathrm{NO}$ [93] and its expression is induced by both $\mathrm{HS}$ and $\mathrm{HC}$ application in grapevine buds during $96 \mathrm{~h}$ of treatment [7] and it may contribute to the reduction of both ROS and RNS generation through the respiratory chain in mitochondria [47]. Therefore, our results are in agreement with the earlier observations that detoxifying mechanisms are correlated with the temporary oxidative stress and $\mathrm{H}_{2} \mathrm{O}_{2}$ may act as a signal in the release of endodormancy in grapevine buds by HC [50]. Taken together, these results support a common mode of ROS regulatory network and its modulation in grapevine dormancy break. For detoxification of RNS, the expression of grapevine HB2 gene peaked at $6 \mathrm{~h}$ post-treatment by PHCN (Fig. 5b). Similarly, the expression of $\mathrm{HB}$ was markedly up-regulated in the $\mathrm{HC}$ treated buds in an earlier study with grape [7]. Besides being an $\mathrm{O}_{2}$ carrier, $\mathrm{HB}$ serves as an electron carrier during the conversion of $\mathrm{NO}$ to $\mathrm{NO}_{3}$ in various tissues [20, 54-57]. Therefore, VvHB2 may play a key role in preventing accumulation of excessive $\mathrm{NO}$ and its toxicity in grape buds during budbreak.

\section{Working model integrating physiological and molecular events during paradormancy release by PHC in grapevine buds}

Earlier studies suggest a general model accounting for the major events occurring during artificially induced bud dormancy release $[4,5,7,13,19,21,45]$. Cellular hypoxia is considered the primary cause that induces budbreak while the increased levels of ROS and NO are the secondary products produced in response to hypoxia. Disturbance in mitochondria leads to a transient oxidative stress 
expressed as an increased level of ROS, decreased activity of TCA cycle and decreased production of ATP and increased production of ethylene. Alternative respiratory pathway, glycolysis, pyruvate metabolism and anaerobic respiration or fermentation is subsequently induced to cope with energy crisis. Our results are in general consistent with this model. However, there are unique features derived from this study that may be attributed to the nature of the plant material used. These studies mainly addressed the release of endodomancy by $\mathrm{HC}$ in the spring, while the present study was focused on the release of paradormncy of grapevine buds in the hot summer. For example, ABA is known to accumulate during the development of endodormancy in grapevine by suppression of bud meristem activity and its degradation mediated by ethylene is critical for dormancy release [5]. It is unlikely that well-irrigated grapevines in the summer accumulate ABA in the paradormant buds. In this study, pruning resulted in a budbreak rate of $33 \%$ (Fig. 1a), which is consistent with paradormancy in the latent buds in the summer as regulated by plant growth regulators originating from other organs (e.g., auxin from the apical meristem), affecting apical dormancy [3, 4]. However, the hormone ethylene is clearly involved in growth resumption in both types of dormancy.

Based on our results and the literature, we propose a working model to integrate the early physiological and molecular events underlying the release of paradormancy by PHC in grapevine buds (Fig. 6). Upon PHC treatment, the release of cyanide $[6,14-16]$ rapidly disturbed aerobic respiration and resulted in cellular hypoxia, and the inhibition of catalase by cyanide promoted $\mathrm{H}_{2} \mathrm{O}_{2}$ accumulation. $\operatorname{ROS}\left(\mathrm{O}_{2}^{*-}, \mathrm{H}_{2} \mathrm{O}_{2}, \mathrm{OH}\right)$ and RNS (NO) were also rapidly produced by $\mathrm{NADPH}$ oxidase/amine oxidase and NADH dependent nitrate reductase/arginine-nitric oxide synthase, respectively. The gaseous NO in turn served as an enhancer in the ROS regulatory network [46]. To prevent the accumulation of lethal levels of ROS/RNS and PCD, the expression of specific genes involved in various metabolic activities (e.g., AOX, SuSy) and antioxidant systems (e.g., FSD, POD72, APX3, GPX2, CAT1, HB2, and pigments) were induced. $\mathrm{H}_{2} \mathrm{O}_{2}$ and $\mathrm{OH}$ activated $\mathrm{Ca}^{2+}$ channels and initiated signal transduction through protein kinase activity, leading to expression of specific stress-

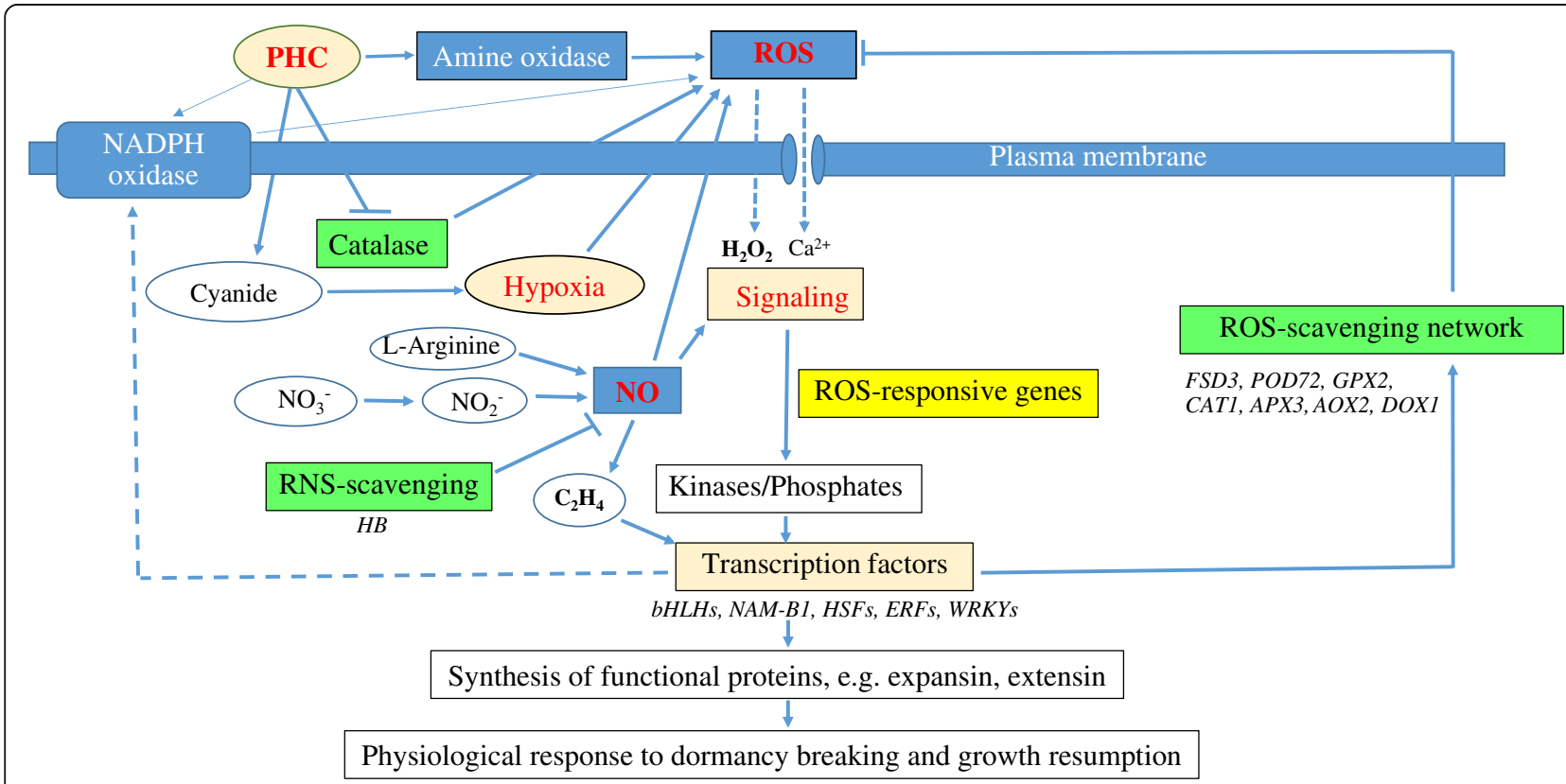

Fig. 6 Proposed mechanistic model for paradormancy release by PHC in grapevine buds. Upon application, HC causes immediate cellular hypoxia through the action of released cyanide on aerobic respiration and inhibition of catalase activity and induces $\mathrm{H}_{2} \mathrm{O}_{2}$ production. $\mathrm{ROS}\left(\mathrm{O}_{2}^{-}, \mathrm{H}_{2} \mathrm{O}_{2} ; \mathrm{OH}\right)$ and RNS (NO) are rapidly produced possibly by several enzymatic systems, such as NADPH oxidase, amine oxidase, nitrate reductase and arginine-nitric oxide synthase. $\mathrm{H}_{2} \mathrm{O}_{2}$ and ethylene act as signaling molecules activating genes involved in antioxidant defense systems. The antioxidant machinery and related pathways (e.g. FSD, POD, DOX, GPX, APX, AOX, HB, etc.) are upregulated to maintain ROS and RNS at sublethal levels to avoid PCD. $\mathrm{H}_{2} \mathrm{O}_{2}$ in the cell wall induces cell wall loosening and expansion. $\mathrm{H}_{2} \mathrm{O}_{2}$ also functions in anabolic, signaling and defense pathways and in the synthesis of the other ROSs; $\mathrm{OH}$ in the presence of $\mathrm{H}_{2} \mathrm{O}_{2}$ and $\mathrm{O}_{2}^{-}$exerts a wall loosening effect, and $\mathrm{H}_{2} \mathrm{O}_{2}$ also drives peroxidase-mediated cross-linking of structural cell wall components. In the signal transduction pathway, ROS triggers the expression of ROS responsive genes. $\mathrm{H}_{2} \mathrm{O}_{2}$ and $\mathrm{OH}$ activate $\mathrm{Ca}^{2+}$ channels and initiate a signal transduction and activate protein kinase activity, which in turn activates different transcription factors to regulate ROS scavenging and ROS producing pathways. Finally, these transcription factors control the downstream functional gene expression responsible for dormancy release and growth resumption in grapevine buds. The accumulation of ethylene in the buds promotes cell elongation and parenchyma formation by activating related ERFs 
responsive TFs (e.g., HSFs, WRKYs, ERFs, HLHs, NAMB1) to regulate ROS producing and scavenging pathways and cellular metabolism [40]. Apoplastic $\mathrm{OH}$ in the presence of $\mathrm{H}_{2} \mathrm{O}_{2}$ and $\mathrm{O}_{2}^{--}$interacted with cell wall component leading to modification of cell wall structure for expansion growth [94]. Whereas the ROS produced in the cytosol or transported from the apoplast served as signal molecules $[15,17]$ and triggered the expression of stress-induced specific TFs for the expression of related downstream functional genes responsible for dormancy breaking and growth resumption (e.g., hormone metabolism, expansin, extension) in grapevine buds. The accumulation of ethylene in the buds promoted cell elongation and chlorenchyma formation by activating related ERFs.

It's clear that the buildup of a sublethal level of ROS and RNS is a common denominator for bud dormancy release in grapevine in response to natural chilling, HS, $\mathrm{P}$ and $\mathrm{HC}$ treatments. Enhanced expression of the antioxidant enzymes GST, APX, GR, GPX, AOX and expansin is also reported by $\mathrm{HC}$ and HS treatment $[7,51,52]$ and during the last stage of chilling requirement in grapevine [53, 64]. Also, genes related to ABA, auxin, ethylene and salicylic acid metabolism are commonly regulated by these treatments. The interplay among these growth regulators leads to cell expansion and division and growth resumption. Thus, judged from the fact that a repertoire of the similar genes is commonly induced by HC, HS, P and natural chilling in a temporary nature, this ROS/NRS regulatory network is essential for the release of bud dormancy in grape and possibly other plants as well.

\section{Conclusion}

In summary, PHC effectively releases paradormancy in grapevine buds in the summer with a rapid accumulation of ROS and RNS and a concomitant transcriptional activation of related genes. Our transcriptional profiling links the rapid transcriptional activation of specific ROS related genes and accumulation of various ROS and RNS underlying the early physiological process during dormant bud break as affected by PHC. The key up- $/$ down-regulated genes identified are all related to ROS metabolism in three important GO categories: peroxidase activity, antioxidant activity and transcription factor. Most of these genes exhibited a peak expression 6-12 h post-treatment, coinciding with the maximum accumulation of ROS at $12 \mathrm{~h}$. The ROS scavenging activities mediated by various antioxidant systems avoid the buildup of lethal levels of ROS and RNS to trigger PCD. The sublethal levels of ROS in turn trigger cell wall loosening and the expression of genes (e.g. expansin, extensin) necessary for cell expansion and extension required for new bud growth as regulated by related hormones (e.g. ethylene). As the overall response to a number of dormancy releasing treatments is remarkably similar, this simplified working model of ROS regulatory network may describe the important molecular and biochemical events during budbreak in grapes and other species as well.

\section{Methods}

\section{Plant material}

The grapevine buds used in this experiment were collected in late August from the mature canes of 5-yearold plants (V. vinifera. x V. labruscana Bailey cv. Kyoho) grown in the research vineyard of the Taichung District Agricultural Research and Extension Station (Taichung DARES, $24^{\circ} 00^{\prime} \mathrm{N}, 120^{\circ} 53^{\prime} \mathrm{E}$, elevation19 M), Changhua County, Taiwan. The day/night temperature in Taichung in Changhua was $27-34{ }^{\circ} \mathrm{C} / 22-27^{\circ} \mathrm{C}$. Plants were fertilized on a regular basis and irrigated with drips on open orchard.

\section{Dormancy release by different treatments}

In late August, uniform grapevine canes (with ca. 25 buds) were identified and divided into three blocks of randomized complete blocks for four treatments: water (as control; $\mathrm{CK})$, pruning (P), $1 \%$ (w/v or $12.5 \mathrm{mM}) \mathrm{HC}\left(\mathrm{H}_{2} \mathrm{CN}_{2}, 50 \%\right.$ stock, Dormex, SKW, Trostberg, Germany) and a combination of $\mathrm{P}$ and $\mathrm{HC}$ (PHC). All treatments were applied to the $8^{\text {th }}$ dormant buds from the base of cane. Control buds were sprayed with water until dripping, while buds for $\mathrm{HC}$ treatment was sprayed with $1 \%(\mathrm{w} / \mathrm{v}) \mathrm{HC}$ until dripping without pruning. For $\mathrm{P}$ treatment, the canes were pruned at $2 \mathrm{~cm}$ apart from the $8^{\text {th }}$ node, and for PHC treatment the buds on the $8^{\text {th }}$ node of the pruned canes were sprayed immediately with $1 \%(\mathrm{v} / \mathrm{v}) \mathrm{HC}$ until dripping. After $24 \mathrm{~h}$ of treatments, buds on ten single-nodes in each treatment were sampled in 3 replications, frozen immediately in liquid nitrogen and stored at $-80{ }^{\circ} \mathrm{C}$ until RNA extraction. Freshly harvested buds before and after treatments were also used for microscopic examination, $\mathrm{H}_{2} \mathrm{O}_{2}$ assay, and in situ detection of $\mathrm{H}_{2} \mathrm{O}_{2}, \mathrm{O}_{2}^{*-}$ and NO. Rates of budbreak were assessed in 30 buds/treatment after 8 days of treatment.

\section{Microscopic observation of bud development after treatments}

Grapevine buds were collected before and after 6, 12, 24, 48 and $96 \mathrm{~h}$ of treatments and fixed in FAA solution for $2 \mathrm{~h}$, washed three times with $1 \mathrm{X}$ PBS buffer $(13.7 \mathrm{mM}$ $\mathrm{NaCl}, 0.27 \mathrm{mM} \mathrm{KCl}, 1 \mathrm{mM} \mathrm{Na} \mathrm{HPO}_{4}$, and $0.18 \mathrm{mM}$ $\mathrm{KH}_{2} \mathrm{PO}_{4}$ ) and embedded into OCT (optimal cutting temperature) compound (Cryomatrix, Thermo Scientific). Longitudinal sections (10 $\mu \mathrm{m}$ thick) were cut with a microtome (Microm HM550, Thermo Scientific), mounted on glass slides, dehydrated at $60{ }^{\circ} \mathrm{C}$ for $1 \mathrm{~h}$, and then stained with filtered $0.1 \%$ Harris Hematoxylin 
solution (HHS, Sigma) for $10 \mathrm{~min}$. Samples were rinsed in cool running double distilled $\mathrm{H}_{2} \mathrm{O}$ for $5 \mathrm{~min}$, followed by $70 \%$ and $100 \% \mathrm{EtOH}$ dehydration before dipping in $0.5 \%$ Erosin ( $1.5 \mathrm{~g}$ dissolved in $300 \mathrm{~mL}$ of $95 \% \mathrm{EtOH}$ ). Finally, the samples were equilibrated in xylene solution before mounting and covering with Leica CV mount. Images of sections were captured with a light microscopy (Axio Imager 2, Carl Zeiss).

\section{Ferric xylenol orange assay of $\mathrm{H}_{2} \mathrm{O}_{2}$}

Frozen grapevine buds $(0.10 \mathrm{~g})$ harvested before and during treatments were ground to fine powder in liquid $\mathrm{N}_{2}$ and then suspended in $2 \mathrm{~mL}$ of $80 \%$ ethanol. After centrifugation, $100 \mu \mathrm{L}$ supernatant was mixed with $1 \mathrm{~mL}$ of reaction solution containing $25 \mathrm{mM} \mathrm{H}_{2} \mathrm{SO}_{4}, 100 \mu \mathrm{M}$ xylenol orange, and $250 \mu \mathrm{M}$ ferrous ammonium sulphate, following the protocol for hydroperoxide assay with the ferric-xylenol orange (Fe-XO) complex [62]. After incubation in the dark for $30 \mathrm{~min}$, the absorbance was read at $560 \mathrm{~nm}$ with $100 \mu \mathrm{M}$ xylenol orange as blank.

\section{In situ $\mathrm{H}_{2} \mathrm{O}_{2}, \mathrm{O}_{2}^{--}$and $\mathrm{NO}$ detection by fluorescence microscopy}

For in situ staining of $\mathrm{H}_{2} \mathrm{O}_{2}, \mathrm{O}_{2}^{--}$and $\mathrm{NO}$, dormant grapevine buds treated with $\mathrm{P}, \mathrm{HC}, \mathrm{PHC}$ and water (as a control) for $12 \mathrm{~h}$ were sectioned (10 $\mu \mathrm{m}$ thickness) and stained for $\mathrm{H}_{2} \mathrm{O}_{2}, \mathrm{O}_{2}^{--}$and $\mathrm{NO}$ with $25 \mu \mathrm{M}$ 2', 7'-dichlorofluorescin diacetate (DCF-DA, Calbiochem, San Diego, CA, USA) [95], $10 \mu \mathrm{M}$ dihydroethidium (DHE, Calbiochem, San Diego, CA, USA) [96], and $10 \mu \mathrm{M}$ 4,5-diaminonaphthalene (DAF-2DA, Calbiochem, San Diego, CA, USA) prepared in $10 \mathrm{mM}$ Tris- $\mathrm{HCl}(\mathrm{pH} 7.4)$, respectively. For negative controls, sections were incubated sequentially with $1 \mathrm{mM}$ sodium pyruvate $\left(\mathrm{H}_{2} \mathrm{O}_{2}\right.$ scavenger $), 1 \mathrm{mM}$ tetramethylpiperdinooxy $\left(\mathrm{O}_{2}^{--}\right.$scavenger $)$, and $1 \mathrm{mM}$ carboxy-PTIO; 2-(4-Carboxyphenyl)-4,4,5,5-tetramethylimidazoline-1-oxyl-3-oxide potassium salt (NO inhibitor), respectively. The bud sections were subsequently washed twice in 1X PBS buffer (13.7 mM NaCl, $0.27 \mathrm{mM} \mathrm{KCl}$, $1 \mathrm{mM} \mathrm{Na}_{2} \mathrm{HPO}_{4}$, and $0.18 \mathrm{mM} \mathrm{KH}_{2} \mathrm{PO}_{4}$ ) for 15 min each and then embedded in $30 \%$ polyacrylamide blocks. The sections were mounted on glass slides and images captured with a fluorescence microscope (Axio Imager 2, Carl Zeiss).

\section{RNA extraction and microarray analysis}

Frozen grapevine buds were ground to fine powder in liquid $\mathrm{N}_{2}$ and RNA was extracted following the protocol of a previous study [97]. Total RNA was purified by RNeasy plant mini columns (Qiagen, Valencia, CA, USA) following the manufacturer's guide, and RNA quality was verified by 2100 Bioanalyzer RNA 6000 nano chip (Santa Clara, CA. USA). The RINs (RNA Integrity Number) for the RNA samples ranged from 8.6 to 10.0, indicative of low degradation.

\section{Probes and gene expression microarray}

The whole genome mRNA sequences of grape were downloaded in FASTA format from http://www.genoscope.cns.fr/ externe/Download/Projets/Projet_ML/data/8X/annotation/ Vitis_ vinifera_mRNA v1.fa and saved into a text file. Sequences in text format were downloaded to the eArray web design application from Agilent Technologies (Santa Clara, CA, USA) for probe design. One probe per target was designed in the sense orientation with a $3^{\prime}$ bias, using base composition methodology as recommended by the manufacturer for gene expression arrays. The best probes were used for generating a custom microarray arranged in a $4 \times 44 \mathrm{~K}$ format, using a randomized lay-out. Each array included 30,128 probes (i.e., 30,128 genes, each gene with 1 probe), $60 \mathrm{bp}$ in length, 1264 positive (spike-in) controls and 153 negative control probes distributed across the array. Positive controls were used as a quality control of the cRNA synthesis, labelling and hybridization steps, whereas negative controls were included to estimate fluorescence background and background variance.

\section{Microarray analyses}

Microarray experiment procedures were carried out following the manufacturer's protocols. Briefly, $1 \mu \mathrm{g}$ of total RNA was amplified by an Agilent Quick Amp Labeling Kit (Agilent Technologies, USA) and labeled with Cy3-CTP or Cy5-CTP (Agilent Technologies, USA). During the in vitro transcription process the treatment sample RNA was labeled by $\mathrm{Cy} 5$ and the control sample RNA was labeled by Cy3. $0.825 \mu \mathrm{g}$ of Cy-labeled cRNA was fragmented to an average size of about 50-100 nucleotides by incubation with fragmentation buffer (Agilent Technologies, USA) at $60 \mathrm{oC}$ for $30 \mathrm{~min}$. Correspondingly fragmented labeled cRNA is then pooled and hybridized to Agilent Whole Grape Genome $4 \times 44 \mathrm{~K}$ oligo microarray (Agilent Technologies, USA) at $65^{\circ} \mathrm{C}$ for $17 \mathrm{~h}$. After washing and drying by nitrogen gun blowing, microarrays were scanned with an Agilent microarray scanner (Agilent Technologies, USA) at $535 \mathrm{~nm}$ for Cy3 and $625 \mathrm{~nm}$ for Cy5. Scanned images were analyzed by Feature Extraction software 10.5 (Agilent Technologies, USA) to quantify signal and background intensity for each feature, and the data were normalized by rank-consistency-filtering LOWESS method. Finally, the GenSpring (Agilent Technologies, USA) software was used to identify significant differentially expressed genes (DEGs). The raw data is available at the Gene Expression Omnibus (http://www.ncbi.nlm.nih. gov/geo/info/linking.html) under the accession GSE86163.

\section{Differentially expressed gene annotation and functional categorization}

A cutoff value of 2-fold change (i.e. the absolute value of $\log _{2} \geq 1$ ) was adopted to identify genes that were 
differentially expressed and considered as potential candidate genes involved in the response to treatments. Gene Ontology (GO) analysis for gene information annotation and functional category distribution frequency was performed using the ErmineJ (version 3.0.2) software $(\max$ class size $=1500$, $\min$ class size $=5)$ [98]. GO terms were assigned according to the gene ontology (www.go_daily-termdb.rdf.xml.gz) and the DBgrapego gene annotation analysis (http://www.genoscope.cns.fr/ externe/Download/Projets/Projet_ML/data/8X/annotation/ prot2go.filtered).

\section{Quantification of gene expression by quantitative RT- PCR (qRT-PCR)}

For qRT-PCR quantitation of gene transcripts upon PHC treatment, grapevine canes were pruned to the $8^{\text {th }}$ dormant buds from the base and the $8^{\text {th }}$ dormant buds were immediately treated with $1 \%(\mathrm{w} / \mathrm{v}) \mathrm{HC}$. Total RNA was extracted at $0,6,12,24,48 \mathrm{~h}$ post-treatment. For each time point, three replicates of bud samples were harvested for RNA extraction. First strand cDNAs was synthesized from $2 \mu \mathrm{g}$ of total RNA using High Capacity cDNA Reverse Transcription Kit (P/N4368814, ABI, USA), according to the manufacturer's instruction. Based on the results of microarray analysis, twelve grape genes, including five, six and one genes coding for ROS-generating, ROS-scavenging and NO-scavenging enzymes, respectively, were selected for quantification of gene expression by qRT-PCR. The forward and reverse primers for candidate and reference genes (Additional file 4) were designed using the primer Express ${ }^{\circ}$ Software v2.0 (ABI, USA). A set of primers was designed for the eukaryotic initiation factor (eIF4A, accession \#CO168508) [64], which served as a reference gene. qRT-PCR was performed using ABI PRISM 7500 Sequence Detection System (ABI, USA). One $\mu \mathrm{L}$ of synthesized cDNA was diluted five folds with water and used as template. Each assay was replicated three times. The amplification of target genes was monitored every cycle by SYBR-Green fluorescence (ABI, USA). PCR amplification begun with an initial denaturing step at $95^{\circ} \mathrm{C}$ for $10 \mathrm{~min}$, followed by 40 cycles of amplification at $95^{\circ} \mathrm{C}$ for $15 \mathrm{~s}, 60^{\circ} \mathrm{C}$ for $60 \mathrm{~s}, 1$ cycle of $95^{\circ} \mathrm{C}$ for $15 \mathrm{~s}, 60^{\circ} \mathrm{C}$ for $60 \mathrm{~s}$, $95^{\circ} \mathrm{C}$ for $15 \mathrm{~s}$ and $60^{\circ} \mathrm{C}$ for $15 \mathrm{~s}$.

\section{Additional files}

Additional file 1: Changes in transcript abundance and clustering of significant differentially expressed genes. Changes in transcript abundance (M/A plot) from the top to bottom, relative mRNA abundance in $P(A), H C$ (B) and PHC (C). The $Y$ - and X-axis show M ( $\log _{2}$ (Normalized Expressions Ratio) (by rank consistency-filtering LOWESS method) and A ( $\log _{2}$ (gBGSubSignal $\mathrm{x}$ rBGSubSignal) ${ }^{1 / 2}$, representing the average signal of the two channels for each gene) obtained from microarray data, respectively. (DOCX $109 \mathrm{~kb}$ )

Additional file 2: 239 up- and 106 down-regulated genes that were common regulated by P, HC and PHC treatments. (XLSX $34 \mathrm{~kb}$ )
Additional file 3: Gene expression levels in ROS-related GO categories. The expression levels of significantly up-/down-regulated genes in the categories of ROS-generating, ROS-scavenging, ROS-specific transcription factors and NO-scavenging in grapevine buds treated with $\mathrm{P}, \mathrm{HC}$ and PHC for $24 \mathrm{~h}$, as revealed by ErmineJ analysis. (XLSX $20 \mathrm{~kb}$ )

Additional file 4: List of primers used for qRT-PCR. (DOCX $16 \mathrm{~kb}$ )

\section{Abbreviations}

ABI5: Abscisic insensitive; ADH: Alcohol dehydrogenase; AOX: Alternative oxidase; APX: Ascorbate peroxidase; Carboxy-PTIO: 2-(4-carboxyphenyl)4,4,5,5-tetramethylimidazoline-1-oxyl-3-oxide potassium salt; CAT: Catalase; DAF-2DA: 4,5-diaminonaphthalene; DCF-DA: 2',',-dichlorofluorescin diacetate; DEGs: Differentially expressed genes; DHAR: Dehydroascorbate reductase; DHE: Dihydroethidium; ERF: Ethylene responsive factor; FAA: Formalin-acetic acidalcohol; Fe-XO: Ferric-xylenol orange; GO: Gene ontology; GPX: Guaiacol peroxidase; GR: Glutathione reductase; GST: Glutathione S-transferase; HCN: Hydrogen cyanamide; KCN: Potassium cyanide; LOXs: Lipoxygenases; MDHAR: Monodehydroascorbate reductase; NO: Nitric oxide; NOS: Nitric oxide synthase-like; NOXs: NADPH oxidases; OCT: Optimal cutting temperature; P: Pruning; PBS: Phosphate-buffered saline; PCD: Program cell death; PDC: Pyruvate decarboxylase; PHCN: Pruning plus hydrogen cyanamide; qRTPCR: quantitative RT-PCR; RBOHs: Respiratory burst oxidase homologues; RNS: Reactive nitrogen species; ROS: Reactive oxygen species; SNP: Sodium nitroprusside; SODs: Superoxide dismutases; SuSy: Sucrose synthase;

TFs: Transcription factors; Trxh: Thioredoxin h; VVAOX: Vitis vinifera alternative oxidase 2; VVAPX3: Vitis vinifera ascorbate peroxidase 3; VVCAT1: Vitis vinifera catalase isozyme 1-like; VvDOX1: Vitis vinifera alpha-dioxygenase; VvERF: Vitis vinifera ethylene response element transcription factor; VVFSD: Vitis vinifera superoxide dismutase; VVFSD3: Vitis vinifera superoxide dismutase 3; VVGPX2: Vitis vinifera glutathione peroxidase 2; VVHB2: Vitis vinifera hemoglobin-2; VVHSF: Vitis vinifera heat stress transcription factor; $V \mathrm{VPOD} 12$ : Vitis vinifera peroxidase 12; VvPOD72: Vitis vinifera peroxidase 72; VvRBOHA: Vitis vinifera respiratory burst oxidase homolog protein A; VVRBOHE: Vitis vinifera respiratory burst oxidase homolog protein E; VVWRKY: Vitis vinifera WRKY transcription factor

\section{Acknowledgements}

The authors acknowledge the supports of the Ph.D. Program of Agriculture Science, National Chiayi University.

\section{Funding}

This research was supported in part by the Council of Agriculture (TW) grant 105AS-9.8.3-FD-Z1, and the Ministry of Science and Technology (TW) grant 104-2221-E-415 -022.

\section{Availability of data and materials}

The raw data is available at the Gene Expression Omnibus (http:// www.ncbi.nlm.nih.gov/geo/info/linking.html) under the accession GSE86163.

\section{Authors' contributions}

YFY and SB planned and designed the study, and SB performed the experiments and analyzed the results and drafted the manuscript. CSC assisted in management of plant material and supervision of the study. HFC assisted in microarray analysis. MSBK assisted data analysis and revised the manuscript. All authors read and approved the final manuscript.

Competing interests

The authors declare that they have no competing interests.

Consent for publication

Not applicable.

Ethics approval and consent to participate Not applicable.

\section{Author details}

'Ph.D. Program of Agricultural Science, National Chiayi University, Chiayi 60004, Taiwan. 'Department of Farmers' Services, Council of Agriculture, Taipei 10014, Taiwan. ${ }^{3}$ Tainan District Agricultural Research and Extension Station, Tainan 71246, Taiwan. ${ }^{4}$ Department of Bioagricultural Sciences, 
National Chiayi University, Chiayi 60004, Taiwan. ${ }^{5}$ School of Biological Sciences, Washington State University, Pullman, WA 99164-4236, USA.

\section{Received: 6 April 2016 Accepted: 4 September 2016 Published online: 15 September 2016}

\section{References}

1. Dokoozlian N, Williams L, Neja R. Chilling exposure and hydrogen cyanamide interact in breaking dormancy of grape buds. HortSci. 1995;30:1244-7.

2. Dokoozlian N. Chilling temperature and duration interact on the budbreak of 'Perlette' grapevine cuttings. HortSci. 1999;34:1-3.

3. Lang G. Dormancy: a new universal terminology. HortSci. 1987;22:817-20.

4. Or E. Grape Bud dormancy release - the molecular aspect. In: Roubelakis-Angelakis KA, editor. Grapevine molecular physiology \& biotechnology. Dordrecht: Springer; 2009. p. 1-29.

5. Zheng C, Halaly T, Acheampong AK, Takebayashi Y, Jikumaru Y, Kamiya Y, Or E. Abscisic acid (ABA) regulates grape bud dormancy, and dormancy release stimuli may act through modification of ABA metabolism. J Exp Bot. 2015;66(5):1527-42.

6. Oracz K, El-Maarouf-Bouteau H, Bogatek R, Corbineau F, Bailly C. Release of sunflower seed dormancy by cyanide: cross-talk with ethylene signalling pathway. J Exp Bot. 2008;59(8):2241-51.

7. Ophir R, Pang X, Halaly T, Venkateswari J, Lavee S, Galbraith D, Or E. Gene-expression profiling of grape bud response to two alternative dormancy-release stimuli expose possible links between impaired mitochondrial activity, hypoxia, ethylene-ABA interplay and cell enlargement. Plant Mol Biol. 2009;71(4-5):403-23.

8. Shulman $Y$, Nir G, Fanberstein L, Lavee S. The effect of cyanamide on the release from dormancy of grapevine buds. Sci Hort. 1983;19:97-104.

9. Or E, Vilozny I, Eyal Y, Ogrodovitch A. The transduction of the signal for grape bud dormancy breaking induced by hydrogen cyanamide may involve the SNF-like protein kinase GDBRPK. Plant Mol Biol. 2000;43(4):483-94.

10. Linsley-Noakes $\mathrm{G}$. Improving flowering of kiwifruit in climatically marginal areas using hydrogen cyanamide. Sci Hort. 1989:38:247-59.

11. Petri J, Stuker H. Effect of mineral oil and hydrogen cyanamide concentrations on apple dormancy, cv. Gala. Acta Hortic. 1996:395:161-8.

12. Jackson J, Bepete M. The effect of hydrogen cyanamide (Dormex) on flowering and cropping of different apple cultivars under tropical conditions of sub-optimal winter chilling. Sci Hort. 1995;60:293-304.

13. Amberger A. Cyanamide in plant metabolism. Int J Plant Physiol Biochem. 2013;5(1):1-10.

14. Sanchez-Perez R, Del Cueto J, Dicenta F, Martinez-Gomez P. Recent advancements to study flowering time in almond and other Prunus species. Front Plant Sci. 2014;5:334.

15. Oracz K, El-Maarouf-Bouteau H, Kranner I, Bogatek R, Corbineau F, Bailly C. The mechanisms involved in seed dormancy alleviation by hydrogen cyanide unravel the role of reactive oxygen species as key factors of cellular signaling during germination. Plant Physiol. 2009;150(1):494-505.

16. Bogatek R, Gawronska H, Oracz K. Involvement of oxidative stress and ABA in CN-mediated elimination of embryonic dormancy in apple. In: Nicolas G, Bradford KJ, Come D, Pritchard HW, editors. The biology of seeds: recent research advances. Oxon: CABI Publishing; 2003. p. 211-6.

17. Oracz K, El-Maarouf Bouteau H, Farrant JM, Cooper K, Belghazi M, Job C, Job D, Corbineau F, Bailly C. ROS production and protein oxidation as a novel mechanism for seed dormancy alleviation. Plant J. 2007:50(3):452-65.

18. Perez $F$, Vergara $R$, Rubio S. $\mathrm{H}_{2} \mathrm{O}_{2}$ is involved in the dormancy-breaking effect of hydrogen cyanamide in grapevine buds. Plant Growth Regul. 2008;55:149-55

19. Vergara R, Parada F, Rubio S, Perez FJ. Hypoxia induces $\mathrm{H} 2 \mathrm{O} 2$ production and activates antioxidant defence system in grapevine buds through mediation of $\mathrm{H} 2 \mathrm{O} 2$ and ethylene. J Exp Bot. 2012;63(11):4123-31.

20. Bykova NV, Hu J, Ma Z, Igamberdiev AU. The role of reactive oxygen and nitrogen species in bioenergetics, metabolism, and signaling during seed germination. In: Gupta JK, Igamberdiev UA, editors. Reactive oxygen and nitrogen species signaling and communication in plants. Cham: Springer International Publishing; 2015. p. 177-95.

21. Perez FJ, Vergara R, Or E. On the mechanism of dormancy release in grapevine buds: a comparative study between hydrogen cyanamide and sodium azide. Plant Growth Regul. 2009;59(2):145-52.
22. Liszkay A, van der Zalm E, Schopfer P. Production of reactive oxygen intermediates $(\mathrm{O}(2)(-), \mathrm{H}(2) \mathrm{O}(2)$, and (.)OH) by maize roots and their role in wall loosening and elongation growth. Plant Physiol. 2004;136(2):3114-23. discussion 3001

23. Potikha TS, Collins CC, Johnson DI, Delmer DP, Levine A. The involvement of hydrogen peroxide in the differentiation of secondary walls in cotton fibers. Plant Physiol. 1999;119(3):849-58.

24. Mittler R. Oxidative stress, antioxidants and stress tolerance. Trends Plant Sci. 2002:7(9):405-10

25. Suzuki N, Miller G, Morales J, Shulaev V, Torres MA, Mittler R. Respiratory burst oxidases: the engines of ROS signaling. Curr Opin Plant Biol. 2011;14(6):691-9.

26. Cona A, Rea G, Angelini R, Federico R, Tavladoraki P. Functions of amine oxidases in plant development and defence. Trends Plant Sci. 2006;11(2):80-8

27. Navrot N, Rouhier N, Gelhaye E, Jacquot J. Reactive oxygen species generation and antioxidant systems in plant mitochondria. Physiol Plantarum. 2007:129:185-95.

28. Karuppanapandian T, Moon J-C, Kim C, Manoharan K, Kim W. Reactive oxygen species in plants: their generation, signal transduction, and scavenging mechanisms. Aust J Crop Sci. 2011;5:709-25.

29. Moller IM. PLANT MITOCHONDRIA AND OXIDATIVE STRESS: electron transport, NADPH turnover, and metabolism of reactive oxygen species. Annu Rev Plant Physiol Plant Mol Biol. 2001;52:561-91.

30. Noctor G, De Paepe R, Foyer CH. Mitochondrial redox biology and homeostasis in plants. Trends Plant Sci. 2007;12(3):125-34.

31. Miller G, Suzuki N, Ciftci-Yilmaz S, Mittler R. Reactive oxygen species homeostasis and signalling during drought and salinity stresses. Plant Cell Environ. 2010:33(4):453-67.

32. Einset J, Nielsen E, Connolly E, Bones A, Sparstad T, Winge P, Zhu J. Membrane-trafficking RabA4c involved in the effect of glycine betaine on recovery from chilling stress in Arabidopsis. Physiol Plantarum. 2007;130:511-8.

33. Marino D, Dunand C, Puppo A, Pauly N. A burst of plant NADPH oxidases Trends Plant Sci. 2012:17(1):9-15.

34. Foreman J, Demidchik V, Bothwell JH, Mylona P, Miedema H, Torres MA Linstead P, Costa S, Brownlee C, Jones JD, et al. Reactive oxygen species produced by NADPH oxidase regulate plant cell growth. Nature. 2003; 422(6930):442-6.

35. Cho KJ, Seo JM, Kim JH. Bioactive lipoxygenase metabolites stimulation of NADPH oxidases and reactive oxygen species. Mol Cells. 2011;32(1):1-5.

36. Porta H, Rocha-Sosa M. Plant lipoxygenases. Physiological and molecular features. Plant Physiol. 2002;130(1):15-21.

37. Brash AR. Lipoxygenases: occurrence, functions, catalysis, and acquisition of substrate. J Biol Chem. 1999;274(34):23679-82.

38. Porta H, Rueda-Benitez P, Campos F, Colmenero-Flores JM, Colorado JM Carmona MJ, Covarrubias AA, Rocha-Sosa M. Analysis of lipoxygenase mRNA accumulation in the common bean (Phaseolus vulgaris L.) during development and under stress conditions. Plant Cell Physiol. 1999;40(8):850-8.

39. Melan MA, Dong X, Endara ME, Davis KR, Ausubel FM, Peterman TK. An Arabidopsis thaliana lipoxygenase gene can be induced by pathogens, abscisic acid, and methyl jasmonate. Plant Physiol. 1993:101(2):441-50.

40. Karkonen A, Kuchitsu K. Reactive oxygen species in cell wall metabolism and development in plants. Phytochemistry. 2015;112:22-32.

41. Jiang F, Zhang Y, Dusting GJ. NADPH oxidase-mediated redox signaling: roles in cellular stress response, stress tolerance, and tissue repair. Pharmacol Rev. 2011;63(1):218-42.

42. Halliwell B. Oxidative stress and neurodegeneration: where are we now? J Neurochem. 2006:97(6):1634-58.

43. Moller IM, Jensen PE, Hansson A. Oxidative modifications to cellular components in plants. Annu Rev Plant Biol. 2007:58:459-81.

44. Balazadeh S, Jaspert N, Arif M, Mueller-Roeber B, Maurino VG. Expression of ROS-responsive genes and transcription factors after metabolic formation of $\mathrm{H}(2) \mathrm{O}(2)$ in chloroplasts. Front Plant Sci. 2012;3:234.

45. Mittler R, Vanderauwera S, Gollery M, Van Breusegem F. Reactive oxygen gene network of plants. Trends Plant Sci. 2004;9(10):490-8.

46. Hancock JT, Neill SJ, Wilson ID. Nitric oxide and ABA in the control of plant function. Plant Sci. 2011;181(5):555-9.

47. del Rio LA, Corpas FJ, Barroso JB. Nitric oxide and nitric oxide synthase activity in plants. Phytochemistry. 2004;65(7):783-92.

48. Alscher RG, Erturk N, Heath LS. Role of superoxide dismutases (SODs) in controlling oxidative stress in plants. J Exp Bot. 2002;53(372):1331-41. 
49. Das K, Roychoudhury A: Reactive oxygen species (ROS) and response of antioxidants as ROS-scavengers during environmental stress in plants. Front Environ Sci 2014;2(53):1-13.

50. Or E, Vilozny I, Fennell A, Eyal Y, Ogrodovitch A. Dormancy in grape buds: isolation and characterization of catalase CDNA and analysis of its expression following chemical induction of bud dormancy release. Plant Sci. 2002;162:121-30.

51. Keilin T, Pang X, Venkateswari J, Halaly T, Crane O, Keren A, Ogrodovitch A, Ophir R, Volpin H, Galbraith D. Digital expression profiling of a grape-bud EST collection leads to new insight into molecular events during grape-bud dormancy release. Plant Sci. 2007;173:446-57.

52. Halaly T, Pang X, Batikoff T, Crane O, Keren A, Venkateswari J, Ogrodovitch A, Sadka A, Lavee S, Or E. Similar mechanisms might be triggered by alternative external stimuli that induce dormancy release in grape buds. Planta. 2008:228(1):79-88

53. Pacey-Miller T, Scott K, Ablett E, Tingey S, Ching A, Henry R. Genes associated with the end of dormancy in grapes. Funct Integr Genomics. 2003;3(4):144-52.

54. Dordas C, Rivoal J, Hill RD. Plant haemoglobins, nitric oxide and hypoxic stress. Ann Bot 2003. 91 Spec No:173-178.

55. Igamberdiev AU, Seregelyes C, Manac'h N, Hill RD. NADH-dependent metabolism of nitric oxide in alfalfa root cultures expressing barley hemoglobin. Planta. 2004;219(1):95-102.

56. Wittenberg JB, Bolognesi M, Wittenberg BA, Guertin M. Truncated hemoglobins: a new family of hemoglobins widely distributed in bacteria, unicellular eukaryotes, and plants. J Biol Chem. 2002;277(2):871-4.

57. Perazzolli M, Dominici P, Romero-Puertas MC, Zago E, Zeier J, Sonoda M, Lamb C, Delledonne M. Arabidopsis nonsymbiotic hemoglobin AHb1 modulates nitric oxide bioactivity. Plant Cell. 2004;16(10):2785-94.

58. Clifton R, Millar AH, Whelan J. Alternative oxidases in Arabidopsis: a comparative analysis of differential expression in the gene family provides new insights into function of non-phosphorylating bypasses. Biochim Biophys Acta. 2006;1757(7):730-41.

59. Brookes PS, Levonen AL, Shiva S, Sarti P, Darley-Usmar VM. Mitochondria: regulators of signal transduction by reactive oxygen and nitrogen species. Free Radic Biol Med. 2002;33(6):755-64.

60. Clifton R, Lister R, Parker KL, Sappl PG, Elhafez D, Millar AH, Day DA, Whelan J. Stress-induced co-expression of alternative respiratory chain components in Arabidopsis thaliana. Plant Mol Biol. 2005;58(2):193-212.

61. Huang $X$, von Rad U, Durner J. Nitric oxide induces transcriptional activation of the nitric oxide-tolerant alternative oxidase in Arabidopsis suspension cells. Planta. 2002;215(6):914-23.

62. Gay C, Collins J, Gebicki JM. Hydroperoxide assay with the ferric-xylenol orange complex. Anal Biochem. 1999;273(2):149-55.

63. Cirami R, Furkaliev D. Effect of time of pruning and hydrogen cyanamide on growth and development of glasshouse-grown cardinal grapes. Aust J Exp Agric. 1991;31:273-8.

64. Mathiason K, He D, Grimplet J, Venkateswari J, Galbraith DW, Or E, Fennell A. Transcript profiling in Vitis riparia during chilling requirement fulfillment reveals coordination of gene expression patterns with optimized bud break. Funct Integr Genomics. 2009:9(1):81-96.

65. Perez F, Burgos B. Alterations in the pattern of peroxidase isoenzymes and transient increases in its activity and in $\mathrm{H}_{2} \mathrm{O}_{2}$ levels take place during the dormancy cycle of grapevine buds: the effect of hydrogen cyanamide. Plant Growth Regul. 2004;43:213-20.

66. Guo C, Guo R, Xu X, Gao M, Li X, Song J, Zheng Y, Wang X. Evolution and expression analysis of the grape (Vitis vinifera L.) WRKY gene family. J Exp Bot. 2014;65(6):1513-28.

67. Licausi F, Giorgi FM, Zenoni S, Osti F, Pezzotti M, Perata P. Genomic and transcriptomic analysis of the AP2/ERF superfamily in Vitis vinifera. BMC Genomics. 2010;11:719.

68. Heim MA, Jakoby M, Werber M, Martin C, Weisshaar B, Bailey PC. The basic helix-loop-helix transcription factor family in plants: a genome-wide study of protein structure and functional diversity. Mol Biol Evol. 2003;20(5):735-47.

69. Borrill P. The NAM-B1 transcription factor and the control of grain composition in wheat. UK: University of East Anglia; 2014

70. Hagenblad J, Asplund L, Balfourier F, Ravel C, Leino MW. Strong presence of the high grain protein content allele of NAM-B1 in Fennoscandian wheat. Theor Appl Genet. 2012;125(8):1677-86.

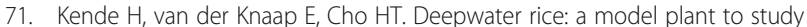
stem elongation. Plant Physiol. 1998;118(4):1105-10.
72. Peeters AJ, Cox MC, Benschop JJ, Vreeburg RA, Bou J, Voesenek LA. Submergence research using Rumex palustris as a model; looking back and going forward. J Exp Bot. 2002;53(368):391-8.

73. Group M. Mitogen-activated protein kinase cascades in plants: a new nomenclature. Trends Plant Sci. 2002;7(7):301-8.

74. Passardi F, Penel C, Dunand C. Performing the paradoxical: how plant peroxidases modify the cell wall. Trends Plant Sci. 2004;9(11):534-40.

75. Riviere MP, Marais A, Ponchet M, Willats W, Galiana E. Silencing of acidic pathogenesis-related PR-1 genes increases extracellular beta-(1->3)glucanase activity at the onset of tobacco defence reactions. J Exp Bot. 2008;59(6):1225-39.

76. Kitajima S, Sato F. Plant pathogenesis-related proteins: molecular mechanisms of gene expression and protein function. J Biochem. 1999;125(1):1-8.

77. Cosgrove DJ. Loosening of plant cell walls by expansins. Nature. 2000; 407(6802):321-6.

78. Yoshiba Y, Aoki C, luchi S, Nanjo T, Seki M, Sekiguchi F, YamaguchiShinozaki K, Shinozaki K. Characterization of four extensin genes in Arabidopsis thaliana by differential gene expression under stress and nonstress conditions. DNA Res. 2001;8(3):115-22.

79. Merkouropoulos G, Barnett DC, Shirsat AH. The Arabidopsis extensin gene is developmentally regulated, is induced by wounding, methyl jasmonate, abscisic and salicylic acid, and codes for a protein with unusual motifs. Planta. 1999;208(2):212-9.

80. Wilson L, Fry J. Extensin-a major cell wall glycoprotein. Plant Cell Environ. 1986:9:239-60.

81. Parcy F, Valon C, Kohara A, Misera S, Giraudat J. The ABSCISIC ACID-INSENSITIVE3, FUSCA3, and LEAFY COTYLEDON1 loci act in concert to control multiple aspects of Arabidopsis seed development. Plant Cell. 1997;9(8):1265-77.

82. Wang $Y, L i L, Y e T, L u Y, C h e n X, W u$ Y. The inhibitory effect of ABA on floral transition is mediated by ABI5 in Arabidopsis. J Exp Bot. 2013;64(2):675-84.

83. Di Cristina M, Sessa G, Dolan L, Linstead P, Baima S, Ruberti I, Morelli G. The Arabidopsis Athb-10 (GLABRA2) is an HD-Zip protein required for regulation of root hair development. Plant J. 1996;10(3):393-402.

84. Baima S, Possenti M, Matteucci A, Wisman E, Altamura MM, Ruberti I, Morelli G The arabidopsis ATHB-8 HD-zip protein acts as a differentiation-promoting transcription factor of the vascular meristems. Plant Physiol. 2001;126(2):643-55.

85. Koyama K, Numata M, Nakajima I, Goto-Yamamoto N, Matsumura H, Tanaka N. Functional characterization of a new grapevine MYB transcription factor and regulation of proanthocyanidin biosynthesis in grapes. J Exp Bot. 2014; 65(15):4433-49.

86. Reyes JC, Muro-Pastor MI, Florencio FJ. The GATA family of transcription factors in Arabidopsis and rice. Plant Physiol. 2004;134(4):1718-32.

87. Schroder H, Langer T, Hartl FU, Bukau B. DnaK, DnaJ and GrpE form a cellular chaperone machinery capable of repairing heat-induced protein damage. EMBO J. 1993:12(11):4137-44.

88. Langer T, Lu C, Echols H, Flanagan J, Hayer MK, Hartl FU. Successive action of DnaK, DnaJ and GroEL along the pathway of chaperone-mediated protein folding. Nature. 1992;356(6371):683-9.

89. Stone SL, Hauksdottir H, Troy A, Herschleb J, Kraft E, Callis J. Functional analysis of the RING-type ubiquitin ligase family of Arabidopsis. Plant Physiol. 2005;137(1):13-30.

90. Shi WM, Muramoto Y, Ueda A, Takabe T. Cloning of peroxisomal ascorbate peroxidase gene from barley and enhanced thermotolerance by overexpressing in Arabidopsis thaliana. Gene. 2001;273(1):23-7.

91. Fuchigami L, Nee C-C. Degree growth stage model and rest-breaking mechanisms in temperate woody perennials. HortSci. 1987;22:836-45.

92. De Leon IP, Sanz A, Hamberg M, Castresana C. Involvement of the Arabidopsis alpha-DOX1 fatty acid dioxygenase in protection against oxidative stress and cell death. Plant J. 2002;29(1):61-2.

93. Gray GR, Maxwell DP, Villarimo AR, McIntosh L. Mitochondria/nuclear signaling of alternative oxidase gene expression occurs through distinct pathways involving organic acids and reactive oxygen species. Plant Cell Rep. 2004;23(7):497-503.

94. Voegele A, Graeber K, Oracz K, Tarkowska D, Jacquemoud D, Tureckova V, Urbanova T, Strnad M, Leubner-Metzger G. Embryo growth, testa permeability, and endosperm weakening are major targets for the environmentally regulated inhibition of Lepidium sativum seed germination by myrigalone A. J Exp Bot. 2012;63(14):5337-50.

95. Tarpey MM, Wink DA, Grisham MB. Methods for detection of reactive metabolites of oxygen and nitrogen: in vitro and in vivo considerations. Am J Physiol Regul Integr Comp Physiol. 2004;286(3):R431-444. 
96. Yamamoto Y, Kobayashi Y, Devi SR, Rikiishi S, Matsumoto H. Aluminum toxicity is associated with mitochondrial dysfunction and the production of reactive oxygen species in plant cells. Plant Physiol. 2002;128(1):63-72.

97. Chang S, Puryear J, Cairney J. A simple and efficient method for isolating RNA from pine trees. Plant Mol Biol Rep. 1993;11:113-6. 1993, 11:113-116.

98. Choi D, Lee Y, Cho HT, Kende H. Regulation of expansin gene expression affects growth and development in transgenic rice plants. Plant Cell. 2003; 15(6):1386-98.

99. Jiang Y, Duan Y, Yin J, Ye S, Zhu J, Zhang F, Lu W, Fan D, Luo K. Genome-wide identification and characterization of the Populus WRKY transcription factor family and analysis of their expression in response to biotic and abiotic stresses. J Exp Bot. 2014;65(22):6629-44.

100. Elmayan T, Simon-Plas F. Regulation of plant NADPH oxidase. Plant Signal Behav. 2007;2(6):505-7.

101. Nakashima K, Takasaki H, Mizoi J, Shinozaki K, Yamaguchi-Shinozaki K. NAC transcription factors in plant abiotic stress responses. Biochim Biophys Acta. 2012;1819(2):97-103.

102. Tsai AY, Gazzarrini S. Overlapping and distinct roles of AKIN10 and FUSCA3 in $A B A$ and sugar signaling during seed germination. Plant Signal Behav. 2012; $7(10): 1238-42$.

103. Kobayashi S, Ishimaru M, Hiraoka K, Honda C. Myb-related genes of the Kyoho grape (Vitis labruscana) regulate anthocyanin biosynthesis. Planta. 2002;215(6):924-33.

104. Carabelli M, Sessa G, Baima S, Morelli G, Ruberti I. The Arabidopsis Athb-2 and -4 genes are strongly induced by far-red-rich light. Plant J. 1993;4(3): 469-79.

105. Mazzucotelli E, Belloni S, Marone D, De Leonardis A, Guerra D, Di Fonzo N, Cattivelli L, Mastrangelo A. The e3 ubiquitin ligase gene family in plants: regulation by degradation. Curr Genomics. 2006; (8):509-22.

\section{Submit your next manuscript to BioMed Central and we will help you at every step:}

- We accept pre-submission inquiries

- Our selector tool helps you to find the most relevant journal

- We provide round the clock customer support

- Convenient online submission

- Thorough peer review

- Inclusion in PubMed and all major indexing services

- Maximum visibility for your research

Submit your manuscript at www.biomedcentral.com/submit 